\title{
Palaeoenvironmental changes and vegetation history of the northern Upper Rhine Graben (southwestern Germany) since the Lateglacial
}

\author{
J.A.A. Bos ${ }^{1, *}$, R. Dambeck ${ }^{2}$, A.J. Kalis ${ }^{3}$, A. Schweizer ${ }^{3}$ \& H. Thiemeyer ${ }^{2}$
}

1 Palaeoecology, Institute of Environmental Biology, Faculty of Science, Utrecht University, Laboratory of Palaeobotany and Palynology, Budapestlaan 4, NL-3584 CD Utrecht, the Netherlands.

2 Institut für Physische Geographie, Johann Wolfgang Goethe-University, P0 Box 11 19 32, D-60054 Frankfurt/Main, Germany.

3 Institut für Archäologische Wissenschaften, Abteilung Vor- und Frühgeschichte, Johann Wolfgang Goethe-University, Grüneburgplatz 1 , D-60323 Frankfurt/Main, Germany.

* Corresponding author. Present address: Department of Paleoclimatology and Geomorphology, Faculty of Earth and Life Sciences, Vrije Universiteit, de Boelelaan 1085, 1081 HV Amsterdam, the Netherlands. Email: hanneke.bos@falw.vu.nl

Manuscript received: February 2005; accepted: April 2006

\begin{abstract}
The vegetation of the northern Upper Rhine Graben (southwestern Germany) is reconstructed for the end of the Lateglacial and the Holocene by means of palynological analyses in combination with AMS ${ }^{14} \mathrm{C}$ dating. Analogous to adjacent lowland areas, the Younger Dryas climatic deterioration did not result in a complete deforestation of the area and open pine woodlands with locally birch stands and shrubs persisted. A subdivision of the Younger Dryas period, into a humid first phase, followed by a dry second phase was also reflected in our records. For the Holocene, the pollen diagrams show two regionally different vegetation developments, related to substrate and variations in annual precipitation: in the south the 'classical' succession of pine then hazel is followed by other deciduous trees, whereas in the northern part, pine kept its dominance far into the Subboreal.
\end{abstract}

Keywords: Lateglacial, Holocene, fluvial sediments, palynology, northern Upper Rhine Graben, Germany.

\section{Introduction}

In this paper emphasis is placed on the reconstruction of the palaeoenvironmental changes and the vegetation development of the northern Upper Rhine Graben during the Lateglacial and Holocene. This is based on an extensive palynological study of a large number of sediment cores recovered from abandoned river channels.

Until recently, the background (i.e. climate, human impact) of the environmental changes, as well as the interaction of their forcing factors was largely unknown. Also a chronological framework was absent. In this respect a multidisciplinary study was carried out using different methods including geomorphological and soil mapping, palynology and various dating techniques on the same archives (Dambeck \& Thiemeyer, 2002;
Dambeck \& Bos, 2002; Dambeck, 2005). The study was part of the German priority research program 'Changes of the geobiosphere during the last 15,000 years - continental sediments as evidence for changing environmental conditions' (Litt, 2003).

The vegetation history of the northern part of the Upper Rhine Graben was previously studied by Rothschild (1936), Grosse-Brauckmann et al. (1990) and more recently by Dambeck \& Bos (2002). The southern part, between Karlsruhe and Mannheim, was studied by Stark (1926), Oberdorfer (1934, 1937), Küttel et al. (1986) and Hölzer \& Hölzer (1994). The latter published the first radiocarbon dated pollen diagram from a site near Karlsruhe, which shows the entire Lateglacial and Holocene. For a detailed palynological study in the southern Upper Rhine area around Freiburg see Schneider 
(2000). In the northern Upper Rhine river valley, pollen analysis was first carried out by Rothschild (1936). At that time radiocarbon dating did not exist and as a consequence a chronostratigraphical framework for the different pollen assemblage zones and vegetation types described by Rothschild is absent. Especially during the Lateglacial and first part of the Holocene, however, palynological records within an area can be used particularly well for relative dating purposes, as various tree and shrub species immigrated, one after another, within a relatively short period (Birks, 1986). Therefore, despite the absence of an absolute time scale, the palynological work by Rothschild (1936) is most valuable and can be used for correlation with the palynological records discussed in this paper, of which many are radiocarbon dated by AMS. GrosseBrauckmann et al. (1990) carried out pollen and plant macro remain analysis on the old Neckar bed in the northern Upper Rhine Graben, while a preliminary overview of a more multidisciplinary study in the northern Upper Rhine area was given by Dambeck \& Bos (2002).

In the present paper we will give an overview of the recent palynological work in the northern Upper Rhine Graben. The palaeoenvironmental changes and vegetation development will be discussed in relation to climate and human impact and associated fluvial processes.

\section{Research area}

The research area is located between Mainz and Lampertheim (Fig. 1), ca. $50 \mathrm{~km}$ south of Frankfurt/Main, in the northern part of the subsiding northern Upper Rhine Graben (Pflug, 1985). The area - between ca. $85-115 \mathrm{~m}$ a.s.l. - is characterised by a wide floodplain of the river Rhine in the west and $a$ narrow floodplain of the tributary river, the Lateglacial Neckar in the east. The ancient character of the landscape with abandoned palaeochannels, oxbow lakes and swamps has largely disappeared during the last centuries as a result of hydrological engineering and modern agriculture.

The research area is situated between low mountain ranges that have a positive influence on the local climate and composition of the vegetation, i.e. on the west on the leeward side of the Rhinehessian hills and plateaus, in the north the Taunus and in the east the Odenwald (Hendl, 1994). The uppermost northern part belongs climatologically to the RhineMain region, which is characterised by relatively mild winters and warm summers (Der Regierungspräsident in Darmstadt, 1985). The largest part of the research area, however, belongs to the Upper Rhine valley. The mean annual temperature is $9.5^{\circ} \mathrm{C}$, with an annual precipitation of $600-700 \mathrm{~mm}$ (Deutscher Wetterdienst, 1981; Klausing, 1988) (Fig. 1). Most of the
Fig. 1. Schematic map of the northern Upper Rhine Graben. Indicated are the different terraces (Older and Lower $t_{6}$ and $\left.t_{7}\right)$, aeolian sand dunes, the three meander belt generations of the Rhine, peat deposits in abandoned channels of the Rhine and Neckar river and annual precipitation values in $\mathrm{mm} / \mathrm{yr}$. Furthermore, the investigated sites are indicated: in the Neckar (blue) and in the Rhine area (yellow - oldest meander generation, green - older meander generation) (modified after Hessisches Landesamt für Bodenforschung, 1990; Fetzer et al., 1995).

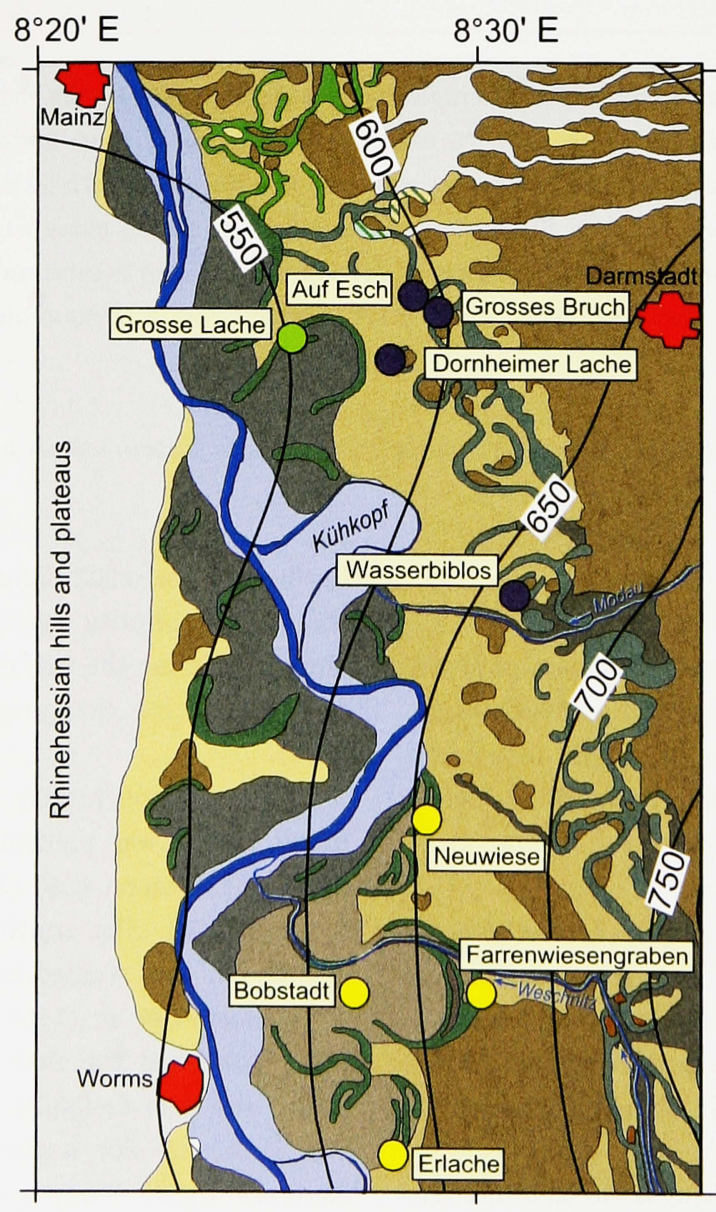

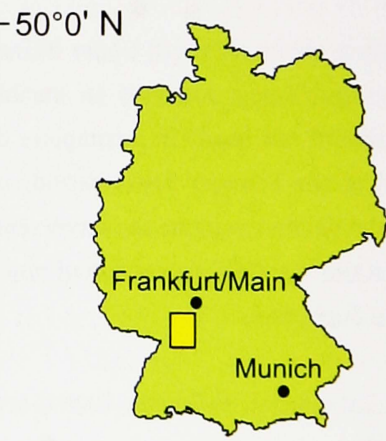

Older terraces, in some parts covered by loess

Lower Terrace, lower level t

Lower Terrace, upper level $t_{6}$

Aeolian sand dunes

Rhine River

Oldest meander belt

Older meander belt

Younger meander belt

Peat deposits in abandoned Rhine River channels

Neckar River

Peat deposits in old Neckar River (Bergstraßen Neckar)

$-600-$ Annual precipitation $\mathrm{mm} \mathrm{yr}^{-1}$ $49^{\circ} 36^{\prime} \mathrm{N}$ 
precipitation, ca. $60 \%$, falls in summer. Evapotranspiration is $<500 \mathrm{~mm}$ year $^{-1}$, which results in a positive water balance (Deneke, 1992; Dommermuth \& Trampf, 1980). Within the area, however, there are variations in annual precipitation that follow an E-W gradient. In the west, at the transition to the Rhinehessian hills and plateaus, precipitation values are lower than average, $<600 \mathrm{~mm}$ year $^{-1}$ (Fig. 1). To the east, precipitation values increase up to $750-800 \mathrm{~mm}$ year $^{-1}$ along the Bergstrassen area, because more rainfall is received on the windward side of the 0denwald (Fig. 1).

During the Quaternary, the northern Upper Rhine Graben was filled-in with up to $400 \mathrm{~m}$ thick fluvial sediments of the river Rhine and its tributaries, i.e., mainly fluvial gravels and sands (Bartz, 1982; Kärcher, 1987; Semmel, 1994; Walter, 1995). The upper part of the Quaternary is characterised by different series of niver terraces, i.e. the Older and Lower Terraces (Fig. 1). The Lower Terrace comprises the period of study, was formed during the last Glacial (Weichselian) and can be subdivided into two levels; an older and a younger one (Scheer, 1978; Schweiss, 1988). The older terrace level (= upper level of the Lower Terrace or Obere Niederterrasse, $t_{6}$ ) is covered with overbank deposits and large aeolian dune fields (Becker, 1967, Kupfahl et al., 1972) (Fig. 1). The younger level (= lower level of the Lower Terrace or Untere Niederterrasse, $t_{7}$ ) is incised into the older $t_{6}$-level and is covered with overbank fines (cf. Hessisches Landesamt für Bodenforschung, 1990), while aeolian sands occur locally in small dune areas.

At the end of the last Glacial, the river Neckar intersected the dunes overlying the upper Lower Terrace level, and started to flow more directly northward, parallel to the western edge of the Odenwald, the so-called Bergstrassen-Neckar. During this period, the Bergstrassen-Neckar flowed into the Rhine near the present-day town of Trebur and created a system of two or three successive meandering river channels, which can be distinguished morphologically by their different channel dimensions (e.g. width, radius) (cf. Mangold, 1892; Hessisches Landesamt für Bodenforschung, 1990; Fig. 1). At the end of the Lateglacial the river shifted its mouth again, this time more southwards to its present position near Heidelberg (Mangold, 1892; Dambeck \& Bos, 2002). Subsequently, the residual meandering main channel of the Bergstrassen-Neckar became completely abandoned and was filled-in with gyttja and peat (Dambeck, 2005). The last Bergstrassen-Neckar bed is morphologically well preserved and can be clearly separated from the channels of older meandering phases. The latter are visibly disconnected from the last main channel.

The present floodplain of the river Rhine developed on the lower level of the Lower terrace (Schweiss, 1988). The floodplain can be subdivided into numerous palaeomeander phases as a result of the large number of abandoned and infilled residual channels (cf. Scharpff et al., 1977; Hessisches Landesamt für Bodenforschung, 1990; Fetzer et al., 1995; Rosenberger et al., 1996; Dambeck, 2005). These 'floodplain terraces' (sensu
Schirmer, 1983) differ mainly on morphological, lithological and pedogenetical criteria and three meander generations could be distinguished; an oldest, older and younger meander generation (e.g. Fetzer et al., 1995; Dambeck \& Sabel, 2001; Dambeck \& Thiemeyer, 2002; Dambeck \& Bos, 2002, Dambeck, 2005) (Fig. 1).

\section{Material and methods}

Sediments were recovered from abandoned river channels by drilling of $1 \mathrm{~m}$ long cores or as monoliths from excavated pits. Overlapping cores were taken to ensure complete sampling. Pollen samples were extracted from the sediment using a small sampler of a known volume $\left(\sim 300 \mathrm{~mm}^{3}\right)$ and prepared for pollen analysis following Fægri \& Iversen (1989). As a result of the relatively high groundwater level in the research area the botanical material was in general well preserved. For classification and identification of pollen types, the keys of Moore et al. (1991), the NEPF, Vol. I-VIII (Punt et al., 1976, 1980, 1981, $1984,1988,1991,1995,2003)$ and a modern reference collection were used. Combined arboreal (AP) and non-arboreal (NAP) totals were employed for percentage calculation. Pollen and spores of the local aquatic- or mire vegetation (including Poaceae and Cyperaceae) were excluded from the pollen sum. Pollen percentage diagrams were divided into regional and local components and constructed using TILIA, TILIA.GRAPH and TG.VIEW computer programs (Grimm, 1991 2004). Regional pollen assemblage zones were established and compared with the biozones of Firbas (1949). In this study, palynological data were also used as a relative dating technique by comparing pollen diagrams reflecting small time intervals with standard pollen diagrams constructed for this region (Table 1 ).

In order to provide a chronostratigraphical framework for the trends in the pollen curves radiocarbon dating was carried out. To reduce the likelihood of contamination by older carbon we preferred to use organic material reflecting atmospheric ${ }^{14} \mathrm{C}$ concentrations, such as seeds and fruits from terrestrial plants (e.g. Marcenko et al., 1989; Törnqvist et al., 1992). Pollen analysis and radiocarbon dating was performed on the same sediment cores, preferably also in combination with sedimentological analysis (compare Dambeck, 2005). Absolute ages are expressed in conventional ${ }^{14} \mathrm{C}$ yrs $\mathrm{BP}$ and calibrated ages in cal BP, i.e. calendar age relative to 1950 .

As two of the profiles (Dornheimer Lache and Grosse Lache) presented here were already analysed in the mid-eighties, bulk samples then were conventionally dated. Three of the sediment samples (i.e., calcareous gyttja) from the Grosse Lache core displayed a considerable hard water effect, therefore a new series including seeds from terrestrial plants was AMS radiocarbon dated (Table 2, Fig. 2). Comparison of the sediment samples and AMS samples shows an age difference of 1100/ $1300{ }^{14} \mathrm{C}$ years or more (Table 2). This is more or less similar to the reservoir age of 1200 years for the present-day water of the river Rhine (Cappers et al., 2002). 
Table 1. Table showing the timing of the abandonment of the palynological investigated residual channels of the Rhine and Neckar rivers. The biostratigraphy follows Firbas (1949, 1952). For each pollen diagram the covering biozones are shown.

\begin{tabular}{|c|c|c|c|c|c|c|c|c|c|c|}
\hline \multirow{2}{*}{\multicolumn{2}{|c|}{ Biostratigraphy }} & \multicolumn{4}{|c|}{ Neckar area } & \multicolumn{5}{|c|}{ Rhine area } \\
\hline & & \multirow[t]{2}{*}{ 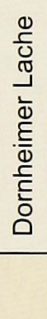 } & \multirow[t]{2}{*}{ 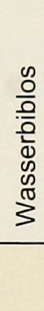 } & \multirow{2}{*}{ 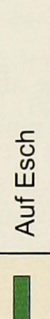 } & \multirow[t]{2}{*}{ 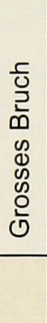 } & \multirow[t]{2}{*}{ 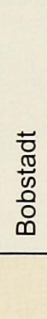 } & \multirow[t]{2}{*}{ 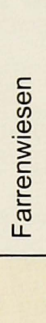 } & \multirow[t]{2}{*}{$\begin{array}{l}\frac{0}{U} \\
\frac{5}{0} \\
\frac{\pi}{2} \\
\text { L }\end{array}$} & \multirow[t]{2}{*}{$\begin{array}{l}0 \\
\infty \\
\frac{\infty}{3} \\
\frac{1}{2} \\
Z\end{array}$} & 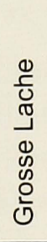 \\
\hline Subatlantic & IX & & & & & & & & & \\
\hline Subboreal & VIII & & & & & & & & & \\
\hline Attontip & VII & & & & & & & & $\Gamma$ & \\
\hline Atramic & VI & & $?$ & & & & & & & \\
\hline Roreal & $\mathrm{Vb}$ & & & & & & & & & \\
\hline & $\mathrm{Va}$ & & & & & $\Pi_{2}$ & D & & & \\
\hline Preboreal & $\mathrm{IVb}$ & & & & & & & & & \\
\hline Preboreal & $\mathrm{IVa}$ & & & & & & & & & \\
\hline $\begin{array}{c}\text { Younger } \\
\text { Dryas }\end{array}$ & III & & & & & & & & & \\
\hline Allerød & II & & & & & & & & & \\
\hline
\end{tabular}

\section{Results}

\section{Neckar area}

\section{Location Dornheimer Lache (Fig. 3)}

The core was collected ca. $12 \mathrm{~km}$ west of Darmstadt (Fig. 1). The sediment sequence shows calcareous gyttja, which more upwards changes into peat. The sequence starts in the Lateglacial (i.e. Allerød biozone), but the since the base of the channel has not been reached the channel may be older. These lower spectra, however, are poor in pollen. Higher in the core, high percentages of Pinus (pine), Betula pubescens type (tree birch) and NAP (especially Artemisia) are recorded. A decrease in the percentages of Pinus and Betula pubescens type and a strong increase in the NAP percentages (e.g. Artemisia, Rumex, Plantago maritima type), shrubs (Betula nana, Juniperus) and Ericales (Calluna, Empetrum) suggest the start of the Younger Dryas biozone. Within the Younger Dryas spectra a subdivision can be made. During the early Younger Dryas, maximal values are recorded of Potamogeton and algae (Pediastrum, Spirogyra). This is followed during the late Younger Dryas by an increase in the values of Myriophyllum spicatum and herbaceous taxa such as Chenopodiaceae and Seseli. The Younger Dryas/ Preboreal transition is marked by a strong increase in the AP values, a decrease in the Artemisia values, and the disappearance of Juniperus, Betula nana type and Empetrum nigrum. High pollen percentages of Pinus and Betula characterise the Preboreal spectra and two marked peaks in the Betula values are recorded. During the late Preboreal, Corylus (hazel) appears. The values of Corylus strongly increase at the transition to the Boreal biozone, while Quercus (oak) and Ulmus (elm) start to show more continuous curves (compare Firbas, 1949, 1952). However, Pinus remains dominant. Higher up in the diagram, the presence of Fagus (beech) and Picea (fir) suggest correlation with the Atlantic. Furthermore, pollen of Acer campestre (maple) and Cerealia are present and high values of Pinus pollen are recorded.

This is the oldest meander infill that was found, the channel was probably abandoned during the Allerød.

\section{Location Wasserbiblos (49०48'16"N; $8^{\circ} 31^{\prime} 42^{\prime \prime} E_{\text {; }}$}

ca. $89.0 \mathrm{~m}$ a.s.l.) (Fig. 4)

The core was collected some $15 \mathrm{~km}$ southwest of Darmstadt (Fig. 1). The basal organic channel fills (i.e. silty gyttja) overly sand and gravels deposited in the active river channel. Later calcareous gyttja was deposited, which is overlain by peat. The pollen diagram (Dambeck \& Bos, 2002) encompasses the Younger Dryas to Atlantic biozones. In the pollen diagram the immigration of various deciduous trees during the Holocene can be followed. Based on the relatively high percentages of NAP and Pinus and the presence of typical Lateglacial taxa the basal sediments are correlated with the Younger Dryas. Similar to the Dornheimer Lache diagram (Fig. 3), a subdivision of the Younger Dryas biozone is based on the presence of aquatic taxa and fluvial transported pollen. During the early Younger Dryas, high values of Potamogeton and fluvial transported pollen are recorded. This is followed during the late Younger Dryas by an increase in the Myriophyllum spicatum values and a decrease in the values of Potamogeton and fluvial transported pollen. The Lateglacial/Holocene transition is characterised by an increase in the AP percentages and a lithological change from minerogenic to organic deposits. During the Preboreal relatively high values of Pinus and Betula pubescens type are recorded. A single peak in the Betula values is recorded during the late Preboreal, with a radiocarbon date of $9300 \pm 240 \mathrm{BP}$ just above this peak. The start of the Boreal biozone is characterised by the expansion of Corylus, which became dominant during the Boreal. This is followed by Ulmus, Quercus and around $8260 \pm 110 \mathrm{BP}$ also by Tilia (Tables 2, 3). Based on the first appearance of Fagus, high values of Quercus and Corylus and a radiocarbon date of $3310 \pm 90 \mathrm{BP}$ the top part of the diagram was initially correlated with the Subboreal biozone (Dambeck \& Bos, 2002). However, there are a number of 
Table 2. Radiocarbon dates (AMS) from the northern Upper Rhine Graben. For calibration, the CALIB 5.0.2 program (Stuiver and Reimer, 1993) and INTCALO4 calibration curve (Reimer et al., 2004) is used. Laboratory No.: Utc. - van der Graaf Laboratory, Utrecht, the Netherlands; KI - Leibniz-Labor Christian Albrechts Universität, Kiel, Germany; KN - Radiocarbon Laboratory, Cologne, Germany.

\begin{tabular}{|c|c|c|c|c|c|c|}
\hline Locality & Depth (cm) & Lab. no. & Age ${ }^{14} \mathrm{C}$ BP & 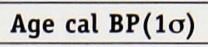 & Dated material & $\delta^{13} \mathrm{C}$ values \\
\hline Wasserbiblos & $82.5-87.5$ & Utc. -9575 & $3310 \pm 90$ & $3680-3440$ & seeds & est. -28.0 \\
\hline Wasserbiblos & $140-145$ & Utc. -9576 & $8260 \pm 110$ & $9410-9090$ & seeds & est. -28.0 \\
\hline Wasserbiblos & $232.5-235$ & Utc. -9577 & $9300 \pm 240$ & $11,060-10,220$ & seeds & est. -28.0 \\
\hline Farrenwiesengraben & $74-81$ & Utc. -7693 & $8750 \pm 60$ & $9890-9630$ & seeds & -27.5 \\
\hline Farrenwiesengraben & $79.5-82$ & Utc. -9370 & $8510 \pm 200$ & $9770-9150$ & seeds & est. -28.0 \\
\hline Grosses Bruch & $145-155$ & Utc. -9371 & $9190 \pm 100$ & $10,490-10,250$ & seeds & -29.6 \\
\hline Neuwiese & $245-254.5$ & Utc. -10561 & $7790 \pm 60$ & $8630-8450$ & seeds & -29.2 \\
\hline Neuwiese & $255.5-261$ & Utc. -10532 & $7650 \pm 70$ & $8540-8390$ & seeds & est. -28.0 \\
\hline Grosse Lache & $135-144$ & Utc. -11382 & $2880 \pm 70$ & $3140-2890$ & seeds & -28.5 \\
\hline Grosse Lache ${ }^{\star}$ & $142-150$ & $\mathrm{KN}-3442$ & $\begin{array}{l}4500 \pm 320 \\
\text { corrected: } \\
3300 \pm 320\end{array}$ & $\begin{array}{l}5590-4730 \\
\text { corrected: } \\
3970-3080\end{array}$ & sediment & \\
\hline Grosse Lache & $144-157$ & Utc. -11383 & $5320 \pm 110$ & $6270-5950$ & seeds & -25.5 \\
\hline Grosse Lache & $161-185$ & Utc. -11384 & $5800 \pm 240$ & $6880-6320$ & seeds & est. -28.0 \\
\hline Grosse Lache & $185-190$ & Utc. -11393 & $5352 \pm 39$ & $6260-6020$ & seeds & -28.8 \\
\hline Grosse Lache* & $334-350$ & KI- 2425 & $\begin{array}{l}6900 \pm 100 \\
\text { corrected: } \\
5700 \pm 100\end{array}$ & $\begin{array}{l}7840-7630 \\
\text { corrected: } \\
6630-6400\end{array}$ & sediment & \\
\hline Grosse Lache* & $365-375$ & $\mathrm{KN}-3444$ & $\begin{array}{l}8000 \pm 1000 \\
\text { corrected: } \\
6800 \pm 1000\end{array}$ & $\begin{array}{l}10,190-7850 \\
\text { corrected: } \\
8700-6470\end{array}$ & sediment & \\
\hline Grosse Lache & $433-441$ & Utc. -11385 & $5800 \pm 220$ & $6880-6320$ & seeds & est. -28.0 \\
\hline Erlache & $93-101$ & Utc.-9369 & $7750 \pm 110$ & $8640-8410$ & seeds & -24.9 \\
\hline Auf Esch & $112-113$ & Utc. -10082 & $3050 \pm 50$ & $3340-3210$ & seeds & -27.5 \\
\hline
\end{tabular}

* The three sediment samples (i.e., calcareous gyttja) from the Grosse Lache core that were dated in the 1980's are biased by a hard water effect. Corrected ages for these samples are given in ${ }^{14} \mathrm{C}$ years $\left(={ }^{14} \mathrm{C}\right.$ sample age -1200 years $)$ and calendar years $\mathrm{BP}$.

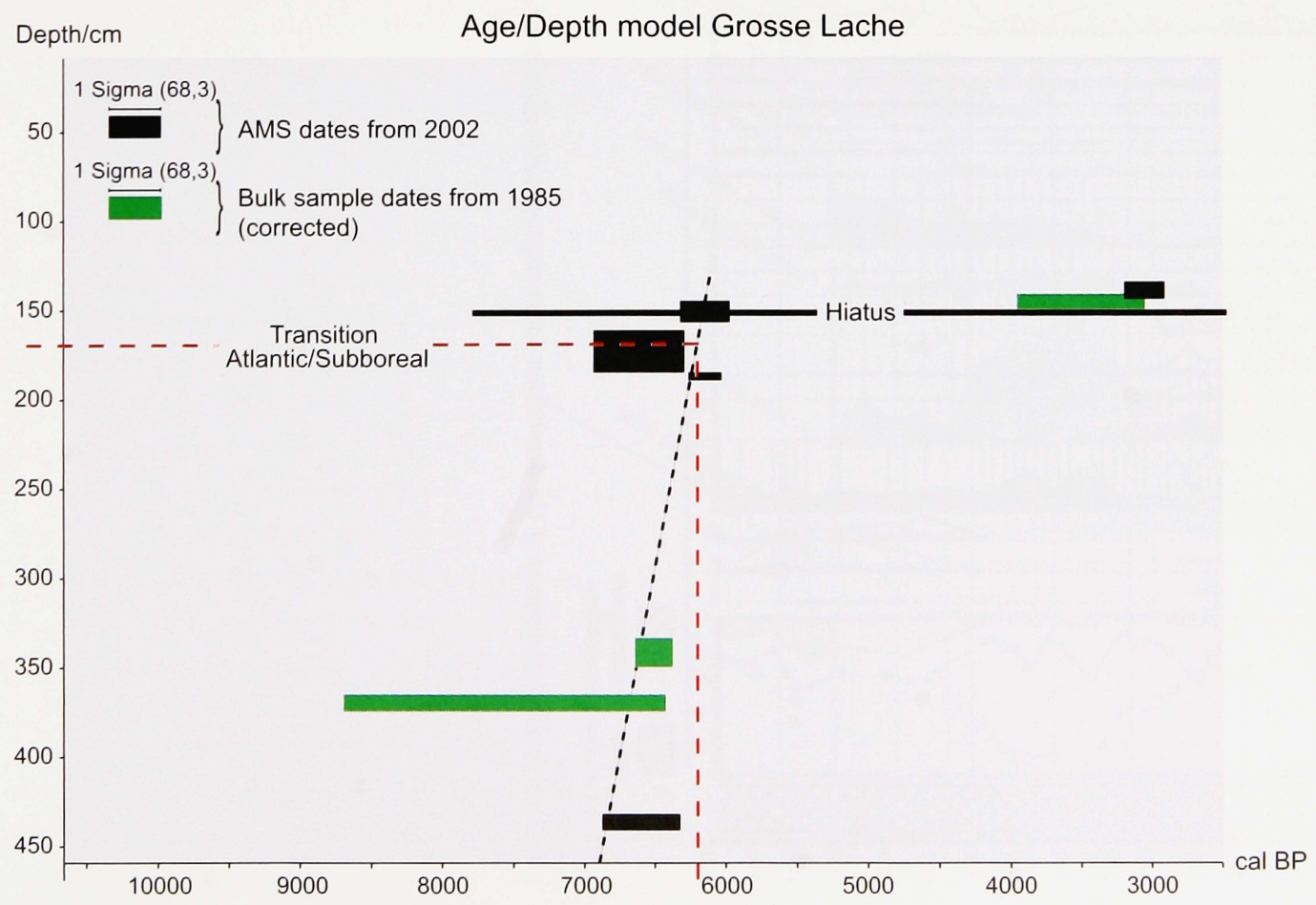

Fig. 2. Age/depth curve of the Grosse Lache sequence. The Atlantic/Subboreal transition was dated at $6200 \mathrm{cal} \mathrm{BP.}$ 


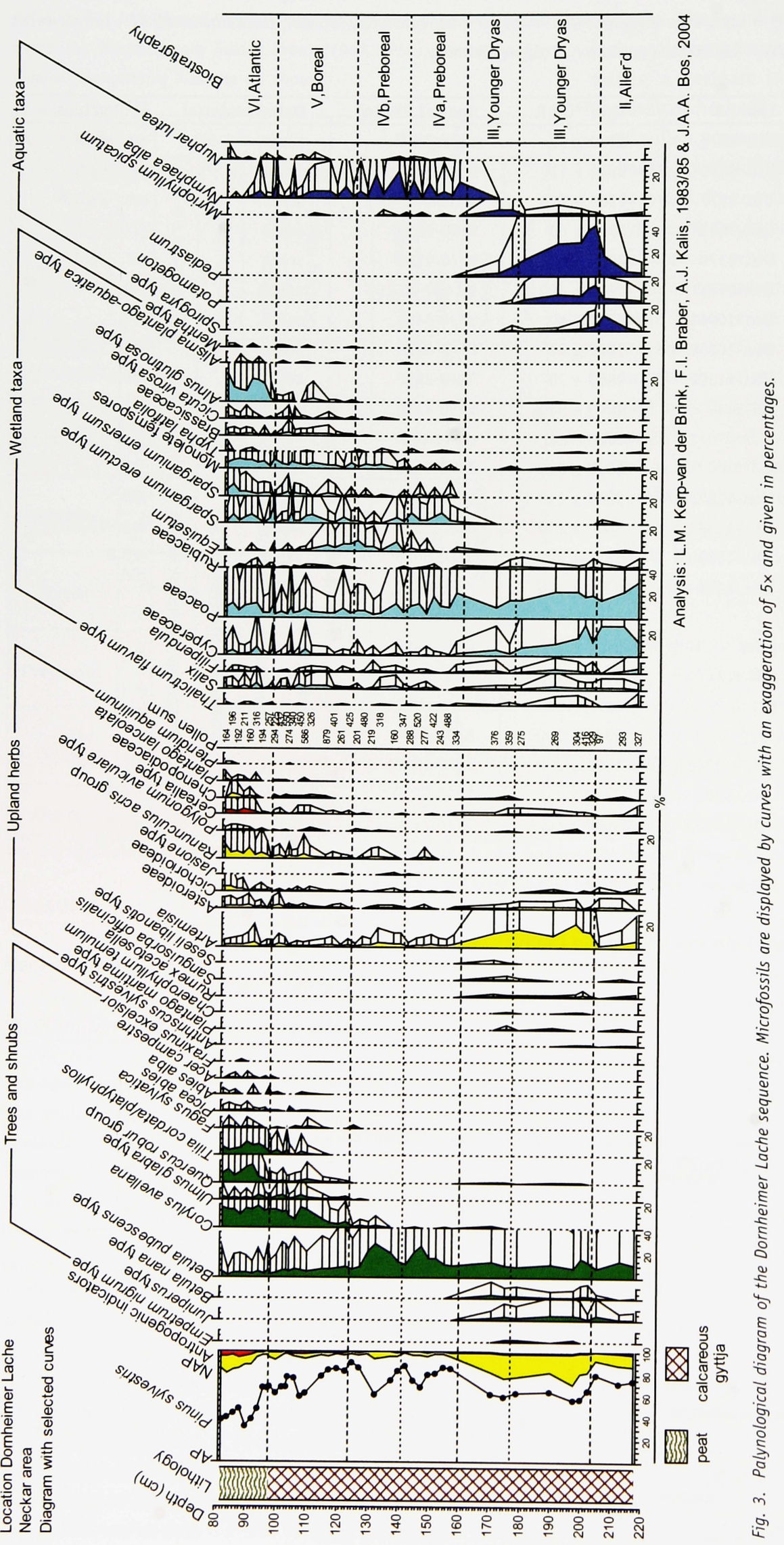




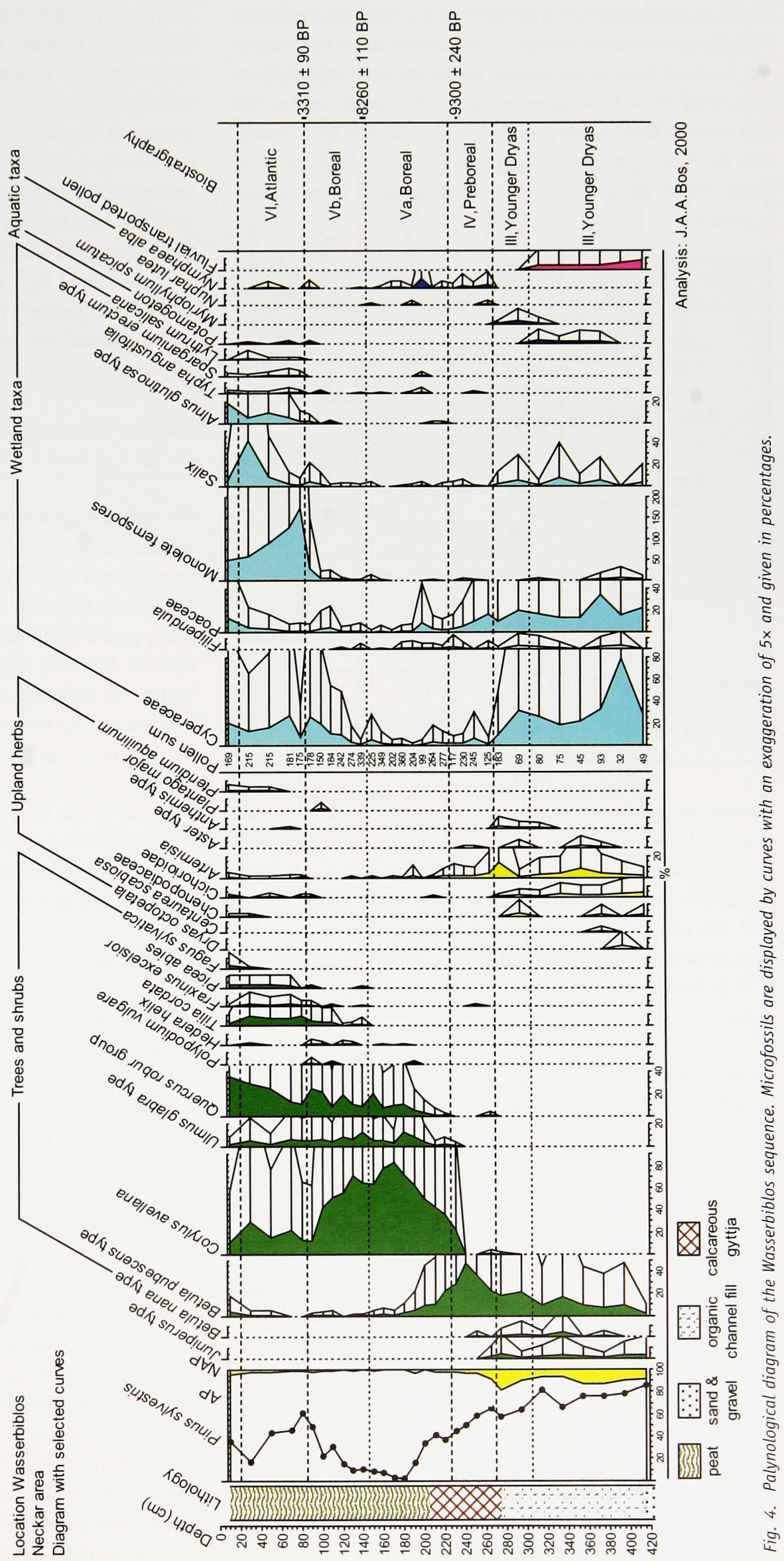


Table 3. A chronostratigraphical framework for the vegetation development and palaeoenvironmental changes in the northern Upper Rhine Graben was developed based on the available radiocarbon dates and age/depth curve of the Grosse Lache sequence (Fig. 2). The calendar ages marked with a number were adapted from the literature, i.e. ${ }^{1}$ Litt et al. (2003), ${ }^{2}$ Van der Plicht et al. (2004), ${ }^{3}$ Schweizer (2001) and ${ }^{4}$ Van Geel et al. (1996, 1998a). Trends in the pollen curves: $\uparrow$ increase, $\Uparrow$ strong increase, $\downarrow$ decrease.

\begin{tabular}{|c|c|c|c|c|}
\hline $\begin{array}{c}\text { Trends in the pollen } \\
\text { curves }\end{array}$ & $\begin{array}{c}{ }^{14} \mathrm{C} \text { Ages } \\
\text { (yr BP) }\end{array}$ & $\begin{array}{l}\text { Ages } \\
\text { cal BP }\end{array}$ & \multicolumn{2}{|c|}{$\begin{array}{l}\text { Biostratigraphy } \\
\text { (Firbas, 1949) }\end{array}$} \\
\hline \multirow{3}{*}{$\begin{array}{l}\text { NAP } \uparrow, \text { Cerealia } \uparrow \\
\text { Fagus } \uparrow \\
\text { Quercus } \uparrow, \text { Fagus } \uparrow \\
\text { Alnus } \uparrow, \text { Ulmus } \downarrow\end{array}$} & & \multirow{3}{*}{$\begin{array}{l}2750^{4} \\
6200\end{array}$} & IX & Subatlantic \\
\hline & $\begin{array}{l}3000 \\
3300\end{array}$ & & VIII & Subboreal \\
\hline & 5500 & & VII & \multirow{3}{*}{ Atlantic } \\
\hline Tila & & $7300^{3}$ & & \\
\hline Quercus $\uparrow$, Tila $\uparrow$ & $-7700-$ & 8500 & $\sqrt{ } 1$ & \\
\hline Corylus $\Uparrow$, Quercus $\uparrow$ & $-8260-$ & 9250 & $\begin{array}{l}\mathrm{Vb} \\
--- \\
\mathrm{Va}\end{array}$ & Boreal \\
\hline Ulmus $\uparrow$, Pinus) & $-9100-$ & 10300 & 1) & \multirow{3}{*}{ Preboreal } \\
\hline Betula $\uparrow$ & -9300 & \multirow{4}{*}{$\begin{array}{l}11250^{2} \\
11590^{1} \\
12680^{1}\end{array}$} & & \\
\hline NAP (Artemisia) $\downarrow$ & & & TVd & \\
\hline \multirow{2}{*}{$\begin{array}{r}\text { NAP (Artemisia) } \uparrow \\
\text { Juniperus, Betula nana } \uparrow\end{array}$} & & & III & $\begin{array}{l}\text { Younger } \\
\text { Dryas }\end{array}$ \\
\hline & & & ॥ & Allerød \\
\hline
\end{tabular}

features that indicate correlation with the Atlantic biozone (Kalis \& Schweizer, 2002). In comparison with other nearby situated pollen diagrams (Figs 3 and 5), the pollen values of Pinus, Tilia and Alnus are too high, while those for Fagus and NAP are too low to correlate with the Subboreal biozone. Quercus becomes dominant during the Atlantic biozone.

This channel must have been abandoned during the Younger Dryas.

Location Auf Esch (49 $54^{\prime} 03^{\prime \prime} N$; 8 $8^{\circ} 28^{\prime} 44^{\prime \prime}$ E;

ca. $87.0 \mathrm{~m}$ a.s.l.) (Fig. 5)

The core was taken from an excavation trench ca. $4 \mathrm{~km}$ north of the location Dornheimer Lache (Fig. 1). The basal sediments consist of mainly sands and gravels and are overlain by peat. Higher up in the sequence, the peat deposits alternate with organoclastic channel fills. The sequence is overlain by a Roman cultural layer and colluvium. The basal part of the pollen diagram (Sojka, 2002) shows relatively high percentages of Artemisia and Pinus, and low percentages of Betula pubescens type and $B$. nana type pollen and is interpreted as a Younger Dryas/Preboreal transitional zone. A decrease in the Artemisia values marks the definite start of the Preboreal. In the Preboreal biozone a single Betula peak is recorded. A sudden increase of the Corylus, Quercus, Ulmus and Tilia pollen values suggests that the early Boreal is absent. The first pollen grains of Fagus and Picea further up in the sequence correlate with the Atlantic biozone. Similar to the nearby Dornheimer Lache, Pinus remains dominant during the Boreal and Atlantic Between the Atlantic and Subboreal biozones a small hiatus is present at the overlap between two successive boxes. A strong increase in the Quercus, Fagus and Alnus glutinosa type pollen percentages marks the start of the Subboreal biozone. Higher up in the core there is a ${ }^{14} \mathrm{C}$ date of $3050 \pm 50 \mathrm{BP}$ (Tables 2, 3). The following Subatlantic biozone (pre-Roman Iron Age phase) is characterised by a strong increase in the NAP and Poaceae values and relatively high values of Fagus.

This channel was probably abandoned at the Younger Dryas/ Preboreal transition.

Location Grosses Bruch (4953'48" N; 8²9'18" E; ca. 86.5 m a.s.l.) (Fig. 6)

The core was collected from the same channel as the Auf Esch sequence, only $1.5 \mathrm{~km}$ more to the southeast (Fig. 1). The channel was filled-in with peat. The relatively high NAP values and presence of typical Lateglacial taxa in the basal sandy peat deposits suggest correlation with the Younger Dryas biozone. However, these taxa also may have been redeposited during the Preboreal as more upwards high AP values (Pinus and Betula) and low values of Corylus suggest correlation with the late Preboreal. The uppermost spectrum shows increasing values of Corylus, Ulmus and Quercus and the ${ }^{14} \mathrm{C}$ date of 9190 $\pm 100 \mathrm{BP}$ at this level gives an accurate age for the Preboreal/ Boreal transition (Tables 2, 3).

This channel was probably abandoned at the Younger Dryas/ Preboreal transition.

\section{Rhine area}

Location Bobstadt (49 $40^{\prime} 02^{\prime \prime} N$; 8 $8^{\circ} 27^{\prime} 16^{\prime \prime} E$; ca. 89.5 m a.s.l.) (Fig. 7)

The core was collected from an early palaeomeander of the oldest meander generation (Fig. 1), ca. $9 \mathrm{~km}$ northeast of Worms. The channel was filled-in with organoclastic channel fills (i.e. clayey silts). The base of the channel has not been reached; therefore the channel abandonment could not be dated precisely. The pollen diagram (Dambeck \& Bos, 2002) represents the transition from late Preboreal (i.e. relatively high values of NAP and Pinus, low percentages of Corylus and Ulmus) to early Boreal biozones (i.e. increasing percentages of Corylus and Ulmus and appearance of Quercus). Pollen of Alnus glutinosa type (includes both A. glutinosa and A. incana) is recorded occasionally. Based on their pollen morphology (e.g. ectoaperture circular to broadly elliptic, protruding aspides and angular outline in polar view, see Blackmore et al., 2003) these pollen grains could be identified as $A$. incana (grey alder)

This channel was abandoned prior to the late Preboreal. 


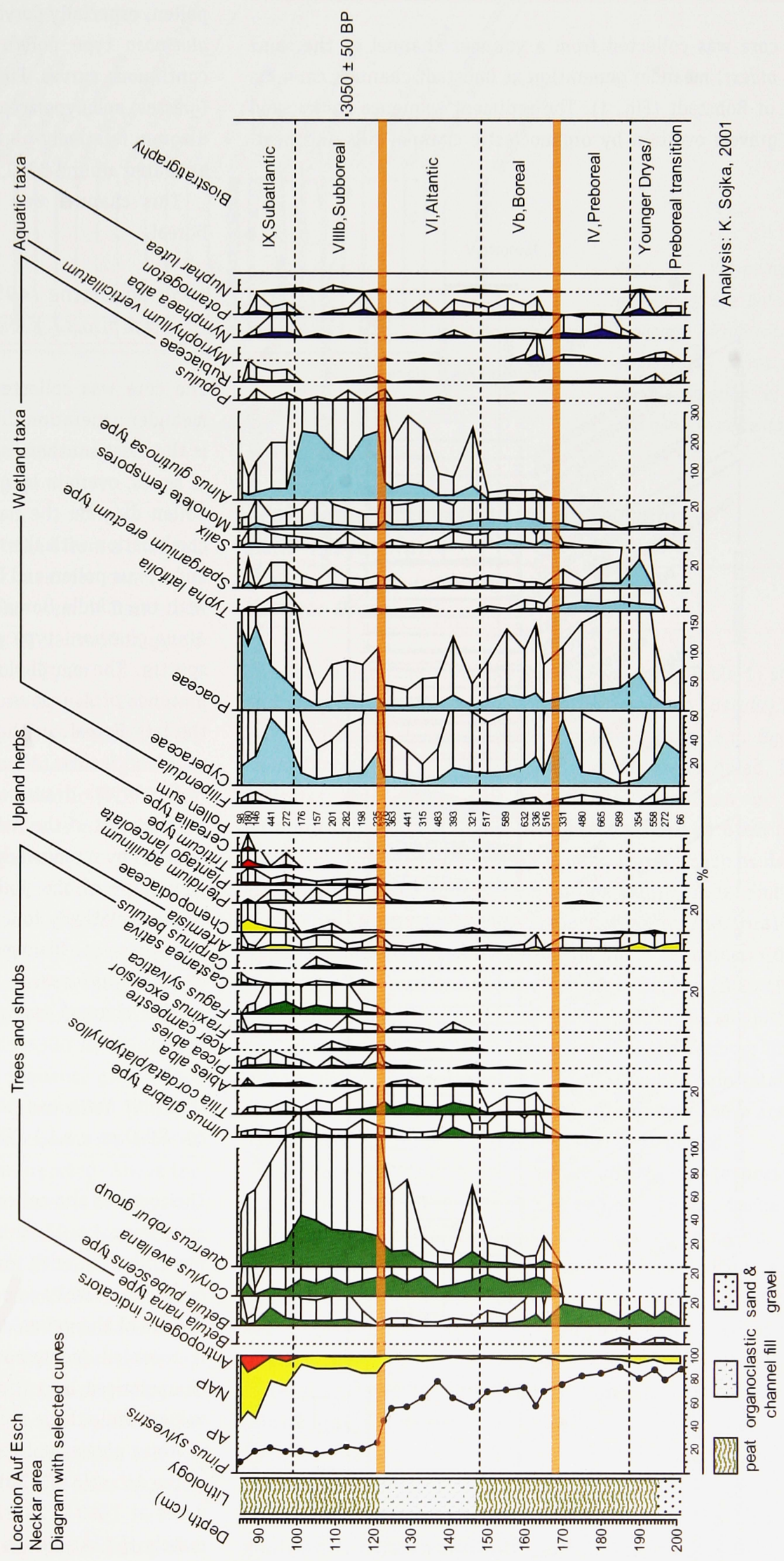


Location Farrenwiesengraben $\left(49^{\circ} 40^{\prime} 00^{\prime \prime} \mathrm{N} ; 8^{\circ} 30^{\prime} 30^{\prime \prime} \mathrm{E}\right.$; ca. $90.0 \mathrm{~m}$ a.s.l.) (Fig. 8)

The core was collected from a younger channel of the same (i.e. oldest) meander generation as Bobstadt channel, ca. $4 \mathrm{~km}$ east of Bobstadt (Fig. 1). The sediment sequence shows sand and gravels overlain by organoclastic channel fills and peat.

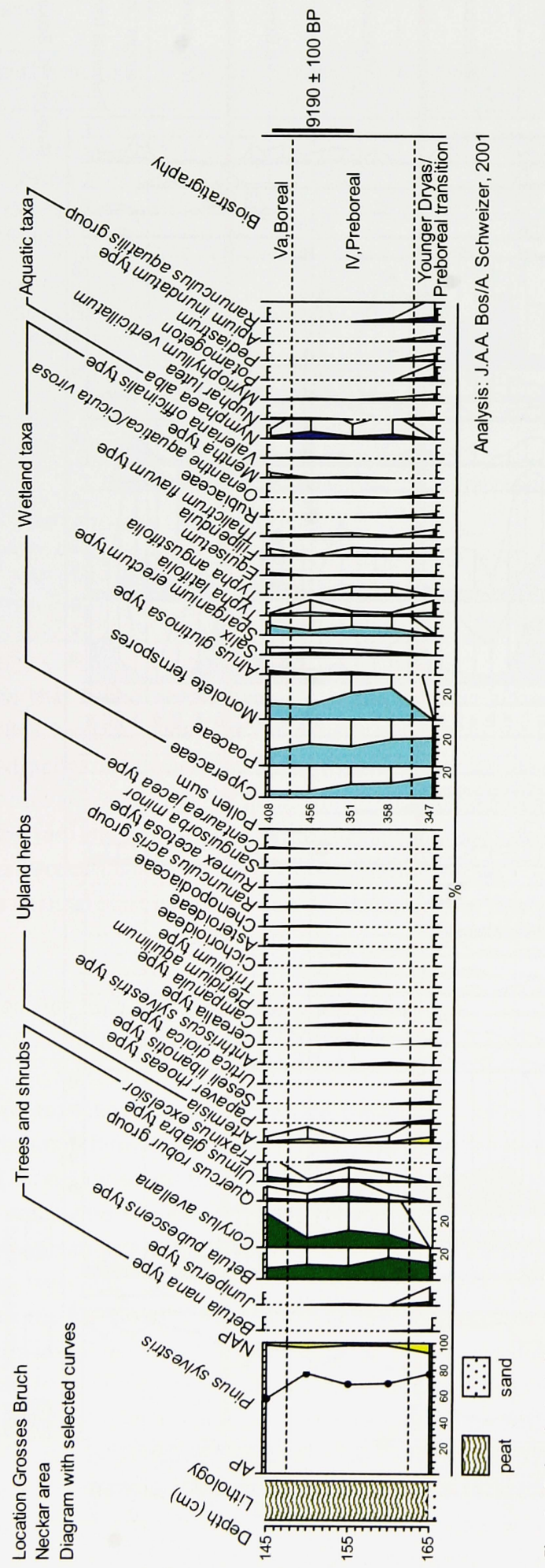

The pollen diagram (Dambeck \& Bos, 2002) shows a typical Boreal pollen spectrum with high percentages of arboreal pollen, especially Corylus and Pinus. Quercus, Ulmus and Alnus glutinosa type pollen (i.e. Alnus incana) are present with continuous curves. Furthermore, high percentages of Poaceae (grasses) and Cyperaceae (sedges) are recorded. At the top of the diagram relatively high values of Corylus are recorded, which are dated around $8750 \pm 60 \mathrm{BP}$ and $8510 \pm 200 \mathrm{BP}$ (Tables 2, 3).

This channel was probably abandoned during the early Boreal.

\section{Location Erlache $\left(49^{\circ} 37^{\prime} 00^{\prime \prime} \mathrm{N} ; 8^{\circ} 28^{\prime} 11^{\prime \prime}\right.$ E; ca. $90.5 \mathrm{~m}$ a.s.l.) (Fig. 9)}

The core was collected from another channel of the oldest meander generation directly north of Lampertheim (Fig. 1). It is the most southern sequence. The basal channel fills consist of sands, overlain by gyttja and peat. In the lower part of the pollen diagram the immigration of Tilia is recorded. This, in combination with the relatively high values of Corylus, Quercus and Ulmus pollen and low values of Pinus, suggests correlation with the middle Boreal. Furthermore, relatively high values of Alnus glutinosa type pollen were recorded in the lower five spectra. The morphology of the pollen grains suggests local presence of $A$. incana. Corylus reaches maximal values during the late Boreal. In the upper part of the diagram, the pollen values of Quercus, Alnus glutinosa type, Tilia and Pinus increase, while Corylus decreases. These are the typical characteristics for the start of the Atlantic biozone (VI, Firbas, 1949), which is dated by a radiocarbon date at $7750 \pm 110 \mathrm{BP}$ (Tables 2, 3). The shape of the pollen grains (e.g. ectoaperture a narrow colpus, relatively low aspides and slightly angular outline in polar view, see Blackmore et al., 2003) suggests local presence of Alnus glutinosa.

This channel was probably abandoned during the middle Boreal.

\section{Location Neuwiese $\left(49^{\circ} 42^{\prime} 24^{\prime \prime} N ; 8^{\circ} 28^{\prime} 32^{\prime \prime} E\right.$; ca. 89.0 m a.s.l.) (Fig. 10)}

The core was also collected from a channel of the oldest meander generation, ca. $15 \mathrm{~km}$ northeast of Worms (Fig. 1). The channel was filled-in with organoclastic channel fills and gyttja, overlying gravel and sand of the active channel. In the lower spectra of the pollen diagram the late Boreal Corylus maximum is recorded (compare Fig. 9). The start of the Atlantic is characterised by an increase in the Quercus, Tilia and Ulmus values, while those of Corylus decrease. Furthermore, the values of Alnus glutinosa type and Poaceae pollen increase. The start of the Atlantic (VI, Firbas, 1949) was dated by two radiocarbon dates at $7650 \pm 70 \mathrm{BP}$ and $7790 \pm 60 \mathrm{BP}$, which is approximately the same as in the Erlache diagram (Tables 2, 3).

This channel was abandoned during the late Boreal. 


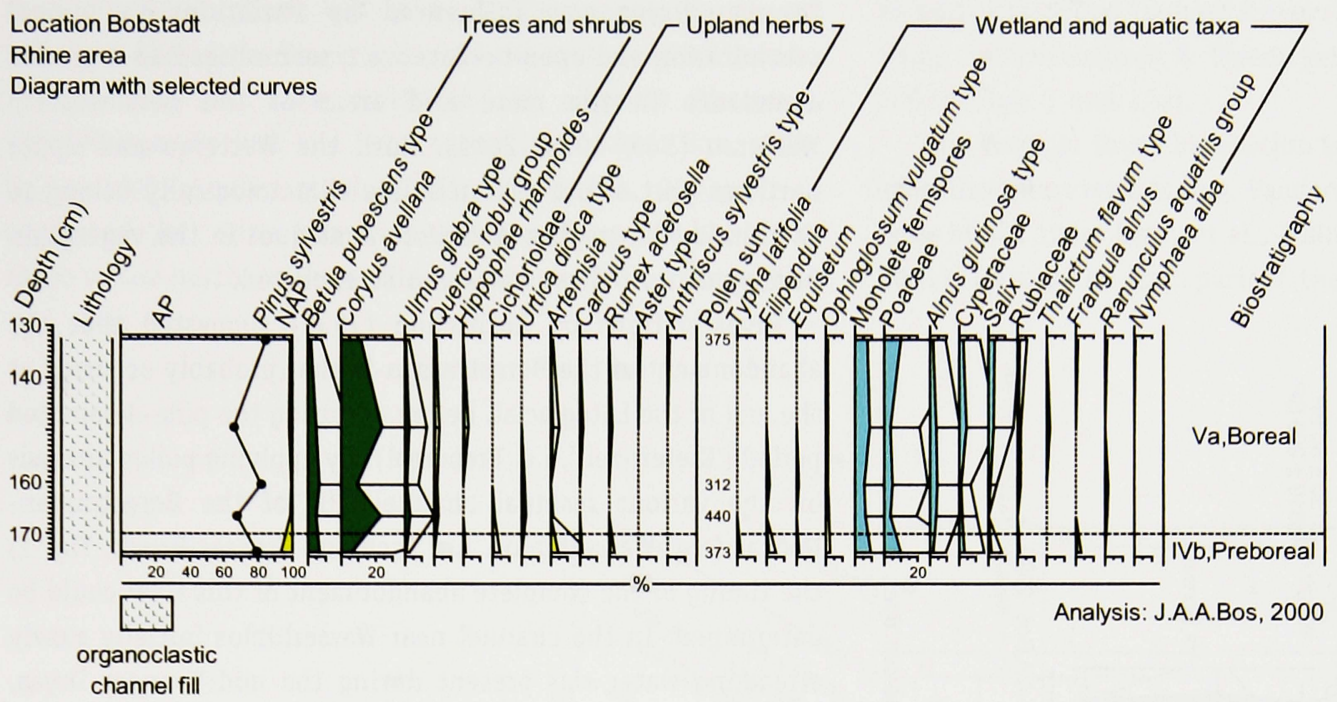

Fig. 7. Palynological diagram of the Bobstadt sequence. Microfossils are displayed by curves with an exaggeration of $5 x$ and given in percentages.

\section{Location Grosse Lache (Fig. 11)}

The most detailed pollen diagram was obtained from a channel, which was attributed first to the older meander generation and was collected in 1983, at about $16 \mathrm{~km}$ west of Darmstadt (Fig. 1). The basal channel fills consist of calcareous gyttja overlain by organoclastic channel fills. Higher up in the sequence gyttja is discontinuously overlain by peat. The lower part of the pollen diagram $(470-370 \mathrm{~cm})$ shows relatively high values of Corylus, Quercus, Tilia, Ulmus and Alnus glutinosa type and can be correlated with the late Atlantic (VII, Firbas, 1949). The Fraxinus excelsior (ash) curve shows some distinct fluctuations. Further upwards in the sequence $(370-310 \mathrm{~cm})$ the Tilia and Corylus values decrease and values of Quercus (ca. 30\%!) increase. At ca. $170 \mathrm{~cm}$ the pollen diagram shows a remarkable decrease in the Ulmus values. This marks the end of the Atlantic. There is a number of radiocarbon dates present from this sequence (Table 2). The AMS radiocarbon dates from the late Atlantic vary between 5800 and 5300 BP (Fig. 11). The age/depth curve of the Grosse Lache sequence gave a date of $6200 \mathrm{cal} \mathrm{BP}$ for the Atlantic/Subboreal transition (Fig. 2). Due to a hiatus at $153 \mathrm{~cm}$, the Subboreal biozone is represented by a few spectra only and therefore not interpreted. Above the hiatus an $8 \mathrm{~cm}$ thick layer is present that consists of reworked material. This is overlain by sediments that show high values of NAP, Poaceae and Fagus pollen and can be correlated with the Subatlantic biozone. The start of the Subatlantic was dated at $2880 \pm 70$ BP (Table 2). Dambeck (2005) demonstrated that a calcic chernozem was present below the more recent top layer (i.e. black clay). Both the buried soil and palynological results indicate an Early Holocene age for the Grosse Lache palaeomeander. This implies that the palaeomeander belongs to the oldest meander generation in stead of the older meander generation.

Abandonment of the river channel took place during the middle Atlantic.

\section{Palaeoenvironmental reconstruction and discussion}

\section{Younger Dryas}

The pollen diagrams from the Neckar river area (Table 1) show relatively high percentages of pine (Pinus), birch (Betula) and NAP, while typical Lateglacial heliophilous taxa (e.g. Betula nana, Centaurea scabiosa, Dryas octopetala) are recorded. This indicates that during this period the vegetation in the northern Upper Rhine Graben was characterised by open pine woodlands with locally birch stands and shrubs, such as dwarf birch (Betula nana), juniper (Juniperus), willow (Salix) and sea buckthorn (Hippophaë) (Fig. 12a). Similar to the southern Upper Rhine valley (Hölzer \& Hölzer, 1994; Schneider, 2000) and to the Wetterau and the Amöneburger Becken (Bos, 1998, 2001) situated further north, our data confirm the suggestion by Rothschild (1936) and Firbas (1952) that the Younger Dryas climatic deterioration did not result in a complete deforestation of the Upper Rhine Graben. From the Rhine area there are no pollen diagrams reflecting the Younger Dryas period.

Furthermore, the higher values of herbs (especially Artemisia) in the pollen diagram of the Dornheimer Lache are probably related to the higher values of pine in the Wasserbiblos pollen diagram. These suggest that open herbaceous communities (indicative of more arid conditions) had a larger abundance in the northeastern part of the research area, while pine was more abundant in the southeastern part (around and south of Crumstadt). This regional contrast in vegetation was probably caused by both the presence of a large sand dune area in the northeastern part of the research area (around and north of Darmstadt), as well as the higher annual precipitation $(>600 \mathrm{~mm}$ ) received by the southeast (compare Fig. 1). Also in the Wetterau, north of our research area, the composition of the vegetation during the 


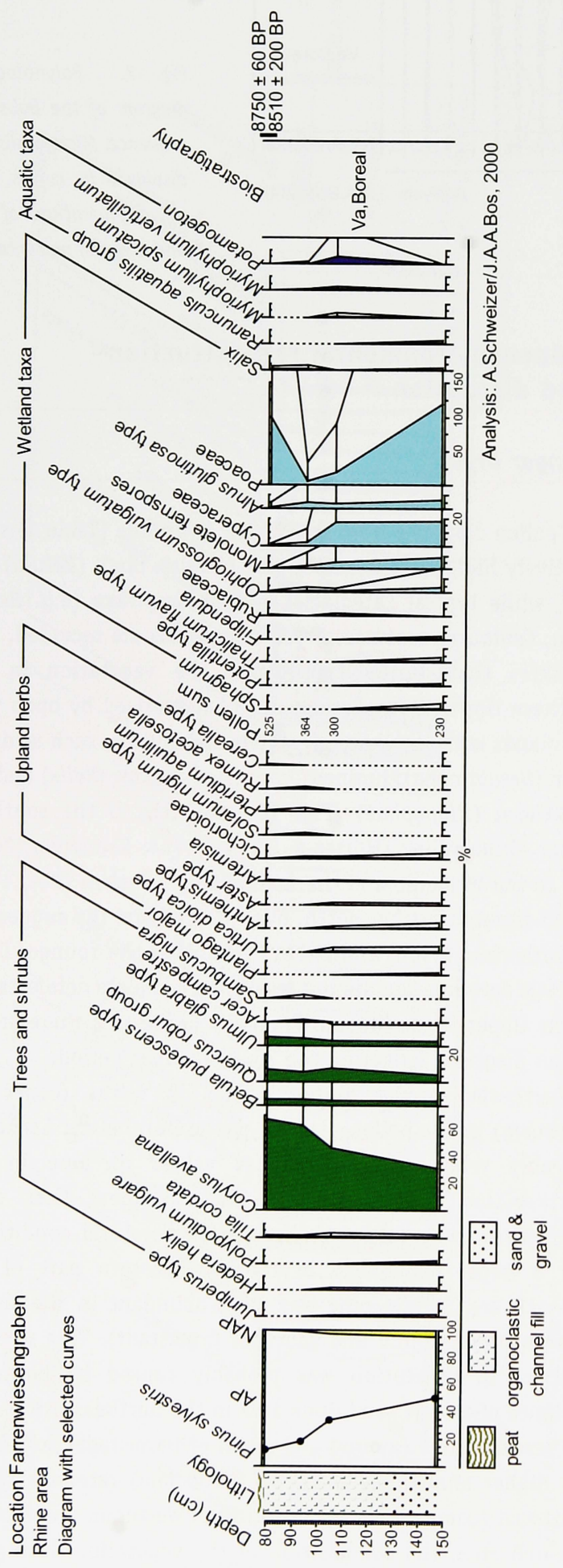

Younger Dryas was influenced by variations in annual precipitation and open herbaceous communities had a greater abundance in the more arid areas of the northwestern Wetterau (Bos, 1998, 2001). Both the Wetterau and upper northern part of our research area climatologically belong to the Rhine-Main region, therefore analogues in the vegetation development of these areas can be expected.

Investigations by Rothschild (1936) suggested that the abandonment of the Bergstrassen-Neckar probably occurred at the end of the Lateglacial, before or during the pine-dominated period ('Kiefernzeit', i.e. Preboreal). By applying pollen analysis on the various residual channel fills of the BergstrassenNeckar (e.g. Wasserbiblos, Auf Esch and Grosses Bruch, Fig. 1) the timing of the complete abandonment of this river could be determined. In the channel near Wasserbiblos initially slowly streaming water was present during the mid-Younger Dryas, but during the late Younger Dryas the water became stagnant (Dambeck and Bos, 2002). In the residual channels near Auf Esch and Grosses Bruch accumulation probably started at the Younger Dryas/Preboreal transition and aquatic vegetation developed with pondweed (Potamogeton) and whorl leaf watermilfoil (Myriophyllum verticillatum). This suggests that the complete abandonment of the Bergstrassen-Neckar occurred at the Younger Dryas/Preboreal transition (Fig. 12a).

During the Lateglacial there were at least two meander generations of the Bergstrassen-Neckar that based on different channel dimensions (i.e. width, radius) morphologically can be well distinguished from each other. The Dornheimer Lache sequence reflects the older meander generation. This channel bed was active from the early Lateglacial to the early Younger Dryas. The Wasserbiblos channel probably belongs to the same river course. The Dornheimer Lache channel, however, was abandoned much earlier, during the Allerød, the Wasserbiblos channel during the mid-Younger Dryas. The Auf Esch and Grosses Bruch sequences both reflect the youngest meander generation, which became active during the early Younger Dryas. This last Bergstrassen-Neckar bed is morphologically well preserved and can be clearly separated from the channels of older meandering phases.

Our records suggest a climatological subdivision of the Younger Dryas period, into a humid first phase, followed by a drier second phase. The Dornheimer Lache and Wasserbiblos diagrams, both show maximal values of algae (i.e. Pediastrum, Spirogyra) and pondweed (Potamogeton) during the early Younger Dryas, which indicates higher water levels due to wetter climatic conditions. During the following part, these taxa were replaced by watermilfoil (Myriophyllum spicatum), suggesting a lowering of the water table due to a drier climate. Records of Chenopodiaceae and Seseli, indicative for disturbed soils, point in the same direction. Moreover, during the early Younger Dryas the Bergstrassen-Neckar channel near Wasserbiblos was still active, but abandonment of this channel followed during a phase with less fluvial dynamics, at the 
start of the drier, second part. Similar phases in fluvial dynamics during the Younger Dryas have been assumed for the Wetter, Ohm and Lahn rivers in the adjacent Wetterau, Amöneburger Becken and Lahn valley (Urz, 1995; Bos, 1998; Nolte, 2000; Andres et al., 2001; Bos \& Urz, 2003). It is suggested that dune formation and reworking of older dune sands in the northern Upper Rhine Graben occurred during the second part of the Younger Dryas (Löscher, 1988; Löscher \& Haag, 1989; Dambeck \& Thiemeyer, 2002; Dambeck \& Bos, 2002) (Figs. 1 and 12a).

This Younger Dryas bipartition is also evidenced in many other European records (e.g. Vandenberghe \& Bohncke, 1985; Lowe et al., 1994; Leroy et al., 2000; Isarin et al., 1998; Bos, 2001). During the first part of the Younger Dryas, various

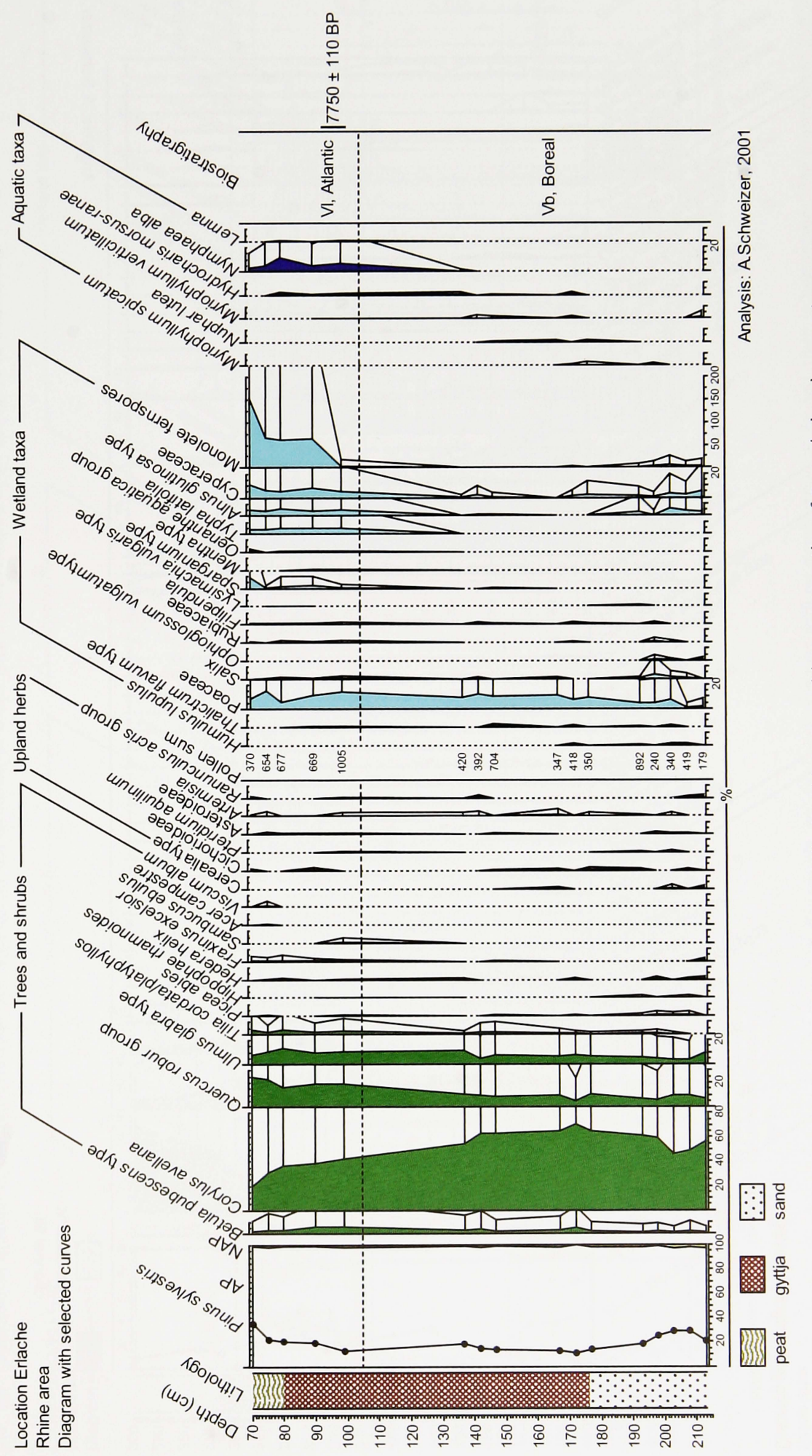




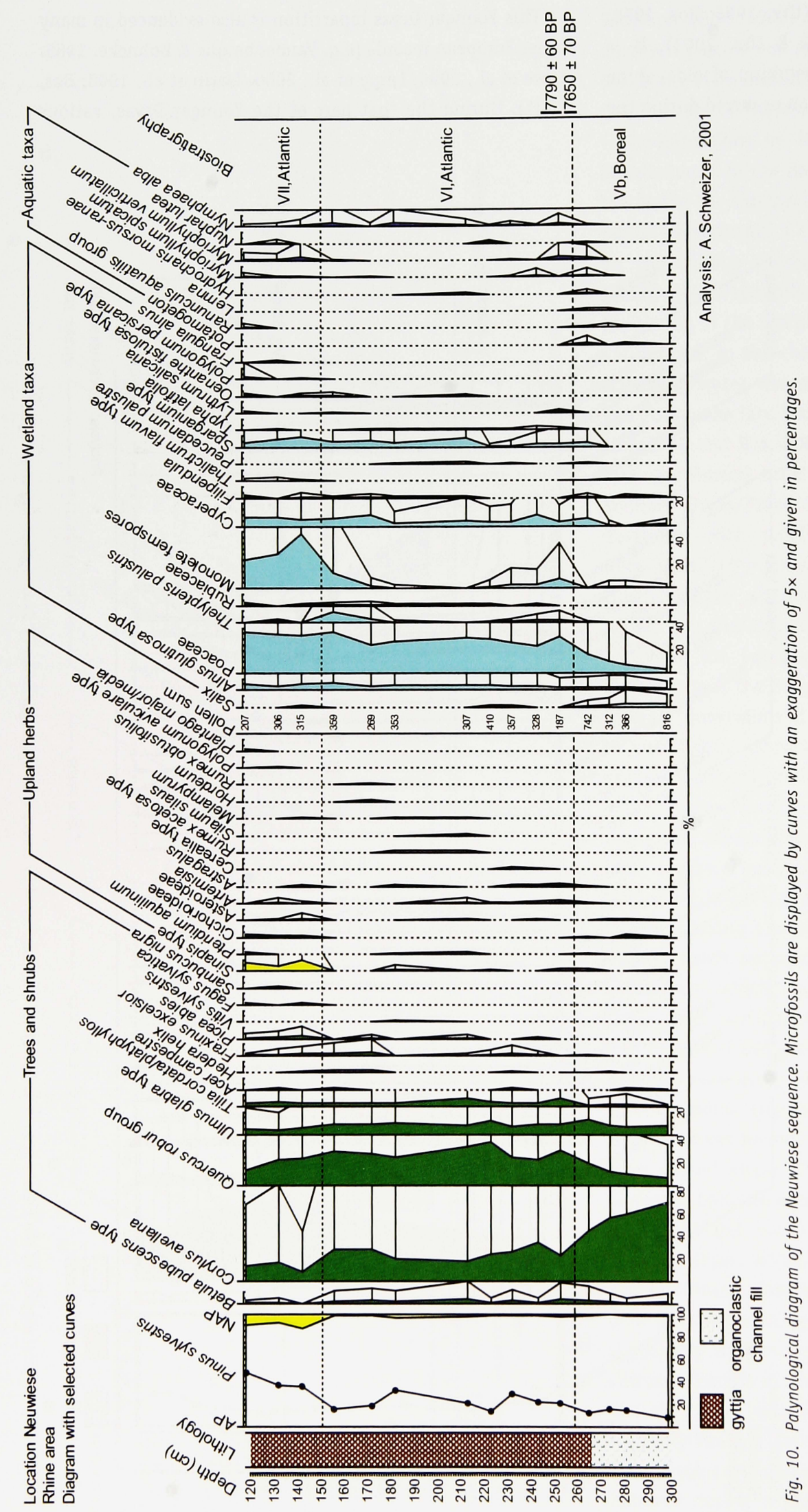




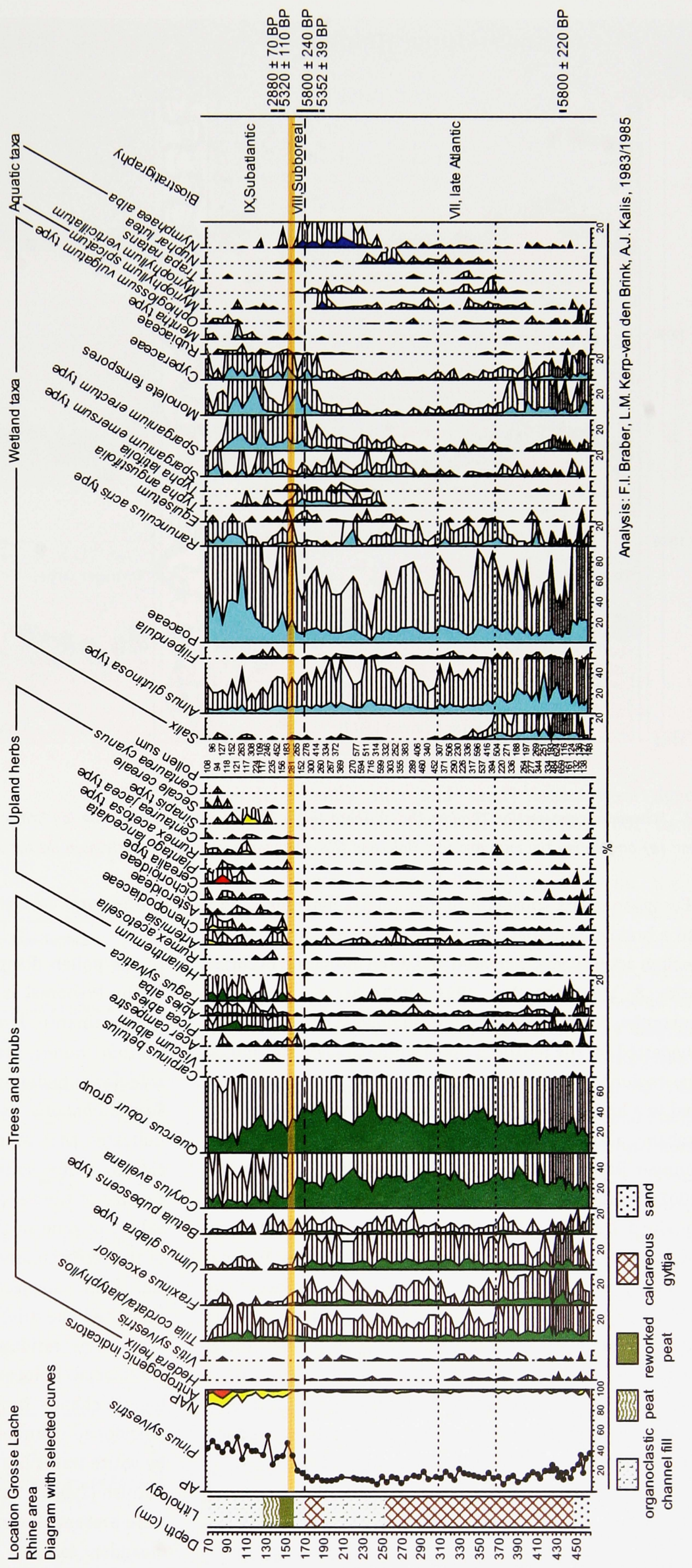




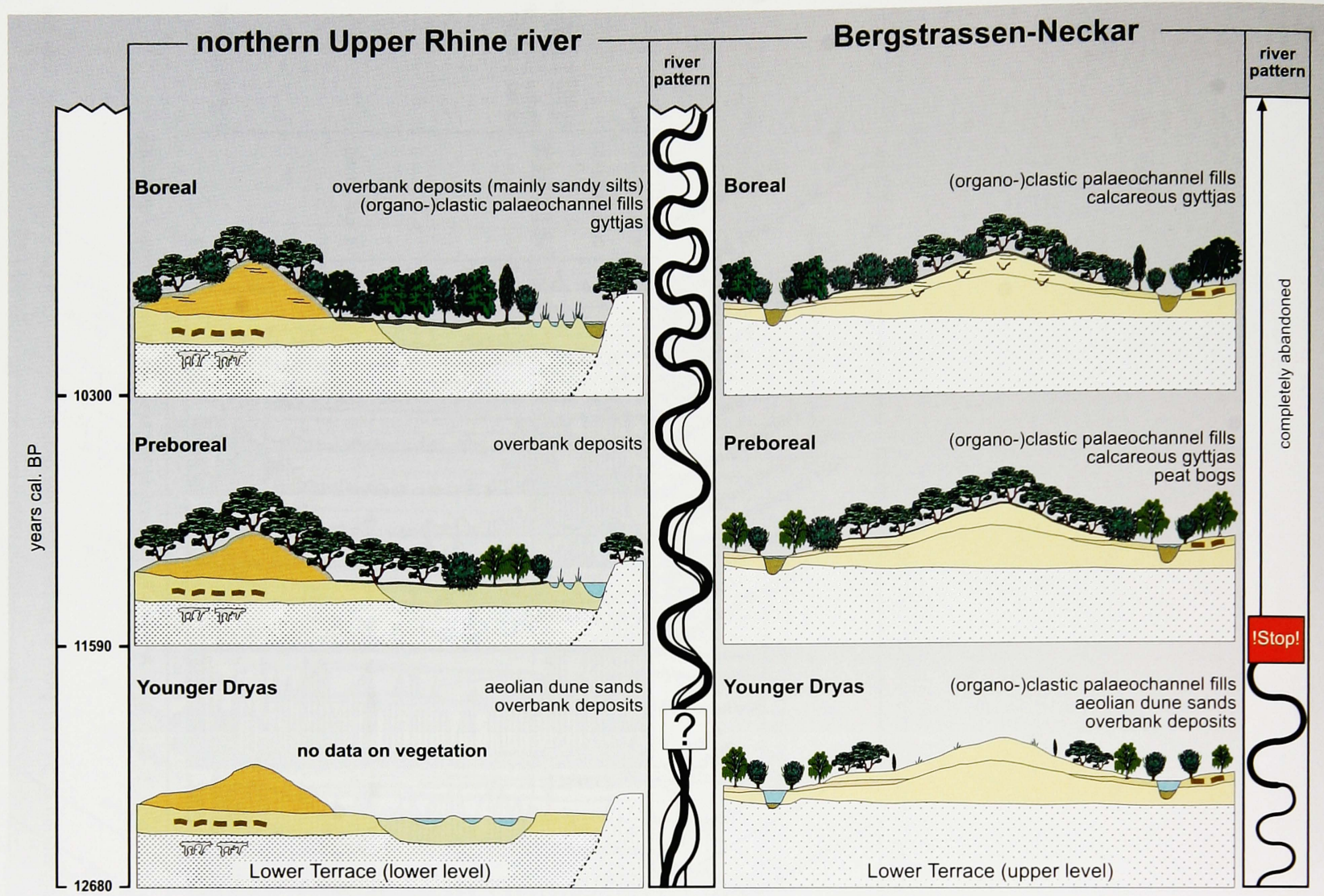

a.

Fig. 12. Schematic cross-section through the northern Upper Rhine Graben showing the landscape evolution during end of the Lateglacial and early Holocene (a) and during the mid-and late Holocene (b). Abandonment of the Bergstrassen-Neckar occurred at the end of the Younger Dryas (= STOP).

large European rivers showed a higher fluvial dynamics and a shift to a braided river pattern, while during the drier second part aeolian activity was increased and dune formation occurred (Bohncke \& Vandenberghe, 1991, Bohncke et al., 1993; Vandenberghe, 1995). A more or less analogous development is thus suggested for the northern Upper Rhine Graben. In contrast to other regions, however, there is no evidence that the rivers changed to a braided river pattern and the Bergstrassen-Neckar and probably also the river Rhine continued meandering during the Younger Dryas (Dambeck \& Thiemeyer, 2002; Dambeck \& Bos, 2002; Dambeck, 2005; Fig. 12a). To some extent this may be explained by the buffering effect the large Rhine river system had against climate change. Moreover, the Younger Dryas cooling did not lead to a complete deforestation of the hinterland, i.e. in the southern part of the Upper Rhine Graben and on the Swiss Plateau (compare Lotter et al., 1992; Hölzer \& Hölzer, 1994; Schneider, 2000) open pine forests remained present. This may have prevented that thresholds for a shift from a meandering system to a braided river pattern (e.g. soil stability, sediment availability/delivery) were crossed.

\section{Preboreal}

In the pollen diagrams of the Neckar area (Table 1) the start of the Preboreal is characterised by an increase in AP values (predominantly Pinus), while juniper (Juniperus), dwarf birch (Betula nana), sea buckthorn (Hippophaë) and typical Lateglacial heliophilous herbaceous taxa (e.g. Dryas octopetala, Seseli libanotis type, Centaurea scabiosa) disappear. This indicates that at the start of the Holocene pine woodlands closed, while soils stabilised as a result of the increased density of the vegetation cover (Fig. 12a). The relatively high values of pine in the pollen records of the northeastern part of the research area (i.e. Dornheimer Lache, Grosses Bruch and Auf Esch) suggest that closed pine woodlands especially inhabited the drier northeastern sand dune area.

In some residual channels of the Bergstrassen-Neckar the Lateglacial/Holocene transition is characterised by a lithological change from minerogenic to organic deposits. In the abandoned channels aquatic vegetation developed dominated by white water lily (Nymphaea alba), while towards the banks bulrush (Typha), burreed (Sparganium) and sedges (Cyperaceae) were present. During this period, the river Rhine continued to meander, forming large meander loops, while on the river 


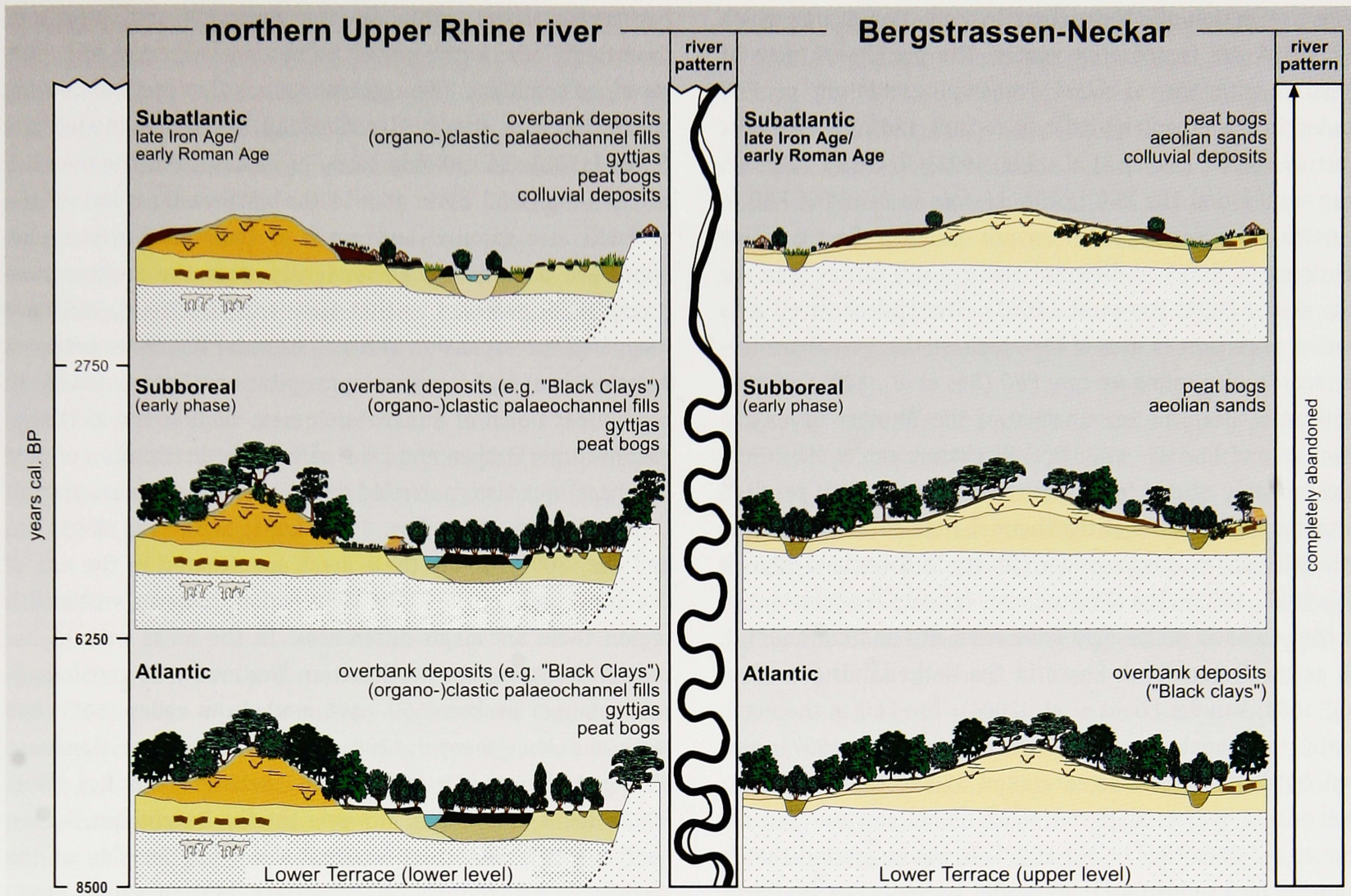

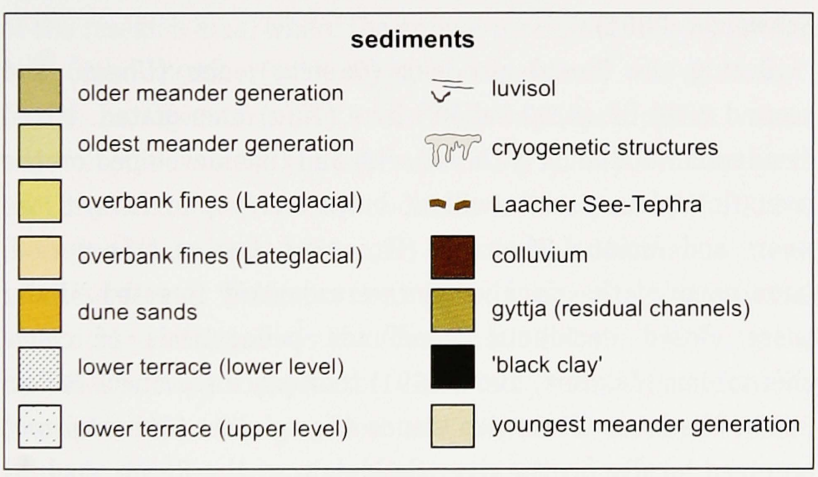

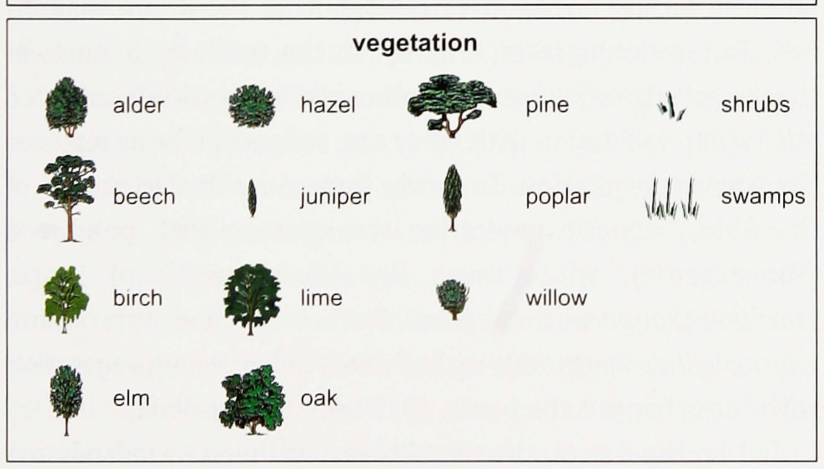

settlements

Legend of Figure 12. floodplain sandy silts and sandy loams were deposited (Dambeck \& Thiemeyer, 2002; Dambeck \& Bos, 2002, Dambeck, 2005) (Fig. 12a).

Birch stands remained locally present on the river floodplains. The higher birch pollen values in the Wasserbiblos diagram, however, indicate that birch stands were more abundant in the southeastern part of the research area, which was probably related to the higher precipitation received by that area (compare Fig. 1). In the Dornheimer Lache diagram two peaks in the birch values are recorded, one during the early Preboreal and one during the late Preboreal (Fig. 3). The first birch peak may be a local phenomenon. The second birch peak of which the end is dated in the Wasserbiblos diagram to $9300 \pm 240 \mathrm{BP}-$ is also present at other localities (Figs. 3-5) and is sometimes accompanied by a peak in the Artemisia values. Furthermore, it is shown in other pollen records of nearby areas: near Karlsruhe with approximately the same date (Hölzer \& Hölzer, 1994), in the northern Wetterau, the Amöneburger Becken and the Lahn valley (Stobbe, 1996; Bos, 1998, 2001; Bos \& Urz, 2003). In the Wetterau this peak is dated to the $9600-9500{ }^{14} \mathrm{C}$ plateau (Stobbe, 1996; Bos, 1998, 2001), which correlates well with results from the central Swiss plateau where a similar birch pollen peak and simultaneous negative excursion in the $\delta^{18} 0$ values was dated around 9500 BP (Lotter et al., 1992). It suggests an expansion of birch stands over larger areas, i.e. on the central Swiss plateau and on the river floodplains of south and central Germany, which 
can be a reflection of a short climatic oscillation during which the climate was temporarily wetter. The birch peak may be correlated with the so-called Preboreal oscillation or PBO recorded in the Greenland ice-core records and north Atlantic terrestrial records (Björck et al. 1996, 1997). Recently, however, it was argued that the $\mathrm{PBO}$ in the ice-core records and $\mathrm{PBO}$ in the north Atlantic terrestrial records do not reflect a single climatic event, but had different timings and causes (Van der Plicht et al., 2004; Bos et al., 2007). The PBO observed as a negative excursion in the $\delta^{18} 0$ values of the Greenland icecore records, also called ice-core PBO (Bos et al., 2007), started ca. 50 years after the termination of the Younger Dryas and centres around 11,450 - 11,350 cal BP (Rasmussen et al., 2007). It was probably caused by a large meltwater flux that resulted in a temporary decrease of the thermohaline circulation in the North Atlantic, causing a colder climate in Greenland (Björck et al., 1996, 1997). The NW European terrestrial equivalent of this cool climatic phase may have been dry and continental, such as the Rammelbeek Phase in the Netherlands (Van Geel et al., 1981; Van der Plicht et al., 2004). The PB0 in the north Atlantic terrestrial records (Björck et al., 1996, 1997), also called terrestrial PBO, started around $11,250 \mathrm{cal} B P$ and was coeval with a sudden shift to a more humid climate (Van der Plicht et al., 2004; Bos et al., 2007). It was suggested that it was forced by a sudden decline in solar activity (Van der Plicht et al., 2004).

Our first birch peak may be correlated with the ice-core PBO in the Greenland ice-core records (compare Van der Plicht et al., 2004, Bos et al., in press.) and with other climatic oscillations described as the Rammelbeek phase in the Netherlands (Van Geel et al., 1981) and the 'youngest Dryas' in northern Germany (Behre, 1966, 1978). The second birch peak is contemporaneous with the terrestrial $P B O$ as recorded in the terrestrial records of northwestern Europe (Björck et al., 1996, 1997) and on the Swiss Plateau (Lotter et al., 1992). The expansion of birch stands over larger areas in central Europe can be a reflection of a shift to a more humid climate.

At the end of the Preboreal at ca. 9300 BP $(10,600$ cal BP), hazel (Corylus) migrates into the Rhine and Neckar river valleys, followed by oak (Quercus) and elm (Ulmus).

\section{Boreal}

During the Boreal the major expansion of hazel (Corylus) took place. Hazel and pine (Pinus) may have grown together on the river terraces and slopes of sand dunes forming open pine forests and hazel scrub (Fig. 12a). As soon as hazel expanded around 9100 BP $(10,300 \mathrm{cal} \mathrm{BP})$, differences in woodland composition within the area become larger (sensu Bos, 2001). Hazel reaches its maximum distribution during the Boreal period, which is similar to the southern Upper Rhine Graben (Schneider, 2000). In the southern part of the northern Upper Rhine Graben, hazel almost completely replaced pine and became dominant, while in the northern part (north of Crumstadt) low hazel pollen values are recorded and pine remained dominant. This regional contrast in vegetation during the Boreal was already described by Rothschild (1936) and Firbas (1952) and can only partly be explained by the presence of the large sand dune area in the northeastern part of the research area (around and north of Darmstadt) where pine may have been growing abundantly. Also the lower annual precipitation received by that area (compare Fig. 1) will have hampered the expansion of hazel, as hazel flourishes better in areas with a higher annual precipitation (Firbas, 1949). In some areas north of our research area, such as the Wetterau, Amöneburger Becken and Lahn valley, the distribution of pine and hazel was also controlled by differences in annual precipitation (Stobbe, 1996; Bos, 1998, 2001; Schweizer, 2001; Bos and Urz, 2003). Today these areas are situated in the one of the driest parts of the Rhine-Main region, however, within this region there are major differences. In the areas with higher precipitation, i.e. the northeastern Wetterau (550 - $650 \mathrm{~mm}$ ), Amöneburger Becken (550 - $600 \mathrm{~mm}$ ), Lahn valley (600 - 650 $\mathrm{mm}$ ) and Vogelsberg (>1200 $\mathrm{mm}$ ) hazel became dominant during the Boreal (e.g. Stobbe, 1996; Schäfer, 1996; Bos, 1998, 2001; Bos \& Urz, 2003). However, in the Butzbacher Becken (northwestern Wetterau) situated on the lee-side of the Rheinische Schiefergebirge - low precipitation values $(<550$ $\mathrm{mm}$ ) led to a continued dominance of pine from the Boreal to far into the Subboreal (e.g. Stobbe, 1996; Bos, 1998, 2001; Schweizer, 2001).

During the Boreal also oak (Quercus), elm (Ulmus) and around 8260 BP (9250 cal BP) lime (Tilia) immigrated. Mixed deciduous woodlands with oak, elm and lime developed on the river floodplains, while willow, birch and poplar fringed the rivers and residual channels (Fig. 12a). During this period, large parts of the river valleys were densely forested. Under these closed deciduous woodlands pedogenesis of calcic chernozems (Zakosek, 1962, 1991) took place (Dambeck \& Bos, 2002). Meadows, often with stands of grey alder (Alnus incana) occurred locally on the river floodplain of the Rhine, such as near Farrenwiesengraben (Fig. 8). In the residual channels of the Bergstrassen-Neckar the hydroseral succession continued and swamp vegetation with reed taxa, sedges and ferns replaced the aquatic vegetation. In newly formed residual channels of the Rhine, aquatic vegetation was present with pondweed (Potamogeton), white water lily (Nymphaea alba), water crowfoot (Ranunculus subgenus Batrachium) and watermilfoil (Myriophyllum spicatum), while a reed/sedge swamp vegetation with ferns fringed the banks (Dambeck \& Bos, 2002).

During the Boreal, the river Rhine continued its meandering pattern and on the floodplain sandy silts and loams were deposited (Dambeck \& Thiemeyer, 2002; Dambeck \& Bos, 2002) (Fig. 12a). Most meanders formed during the Preboreal were abandoned at the end of the Preboreal or during the early Boreal, i.e. Bobstadt respectively Farrenwiesengraben (Fig. 1). 
The Farrenwiesen meander shows a very large radius and channel width. During the late Preboreal to the middle Boreal the radius of the channels increased when the Rhine migrated laterally ca. $4 \mathrm{~km}$ eastward. The meanders that developed during the Boreal (Erlache, Neuwiese; Fig. 1) were of much smaller magnitude (cf. Scharpff et al., 1977). During the Boreal there is a gradual shift in the meandering pattern, which is characterised by a decrease in radius and channel width and the development of more single-thread channels (Dambeck \& Thiemeyer, 2002; Dambeck \& Bos, 2002). The increased density of the vegetation cover in our research area and in the hinterland of the river Rhine (compare Hölzer \& Hölzer, 1994; Burga, 1988) and subsequent higher evapotranspiration probably caused a lowering of the channel-forming discharge and river activity in general.

\section{Atlantic}

At the start of the Atlantic period, ca. 7700 BP (8500 cal BP), the river valleys of the northern Upper Rhine Graben were densely forested. Lime (Tilia) became a more important element in the woodlands and also ash (Fraxinus excelsior) and maple (Acer campestre) appeared. On the river floodplains mixed deciduous woodlands were present with elm (Ulmus), lime (Tilia), hazel (Corylus) and oak (Quercus) (Fig. 12b). Lime and hazel also could be found on the river terraces and pines inhabited the sand dunes (Fig. 12b). In the south eastern part of the research area, where the annual precipitation is $>600 \mathrm{~mm}$, oak, often together with hazel, elm and lime, was dominant. In the northwestern part, relatively high oak pollen values were recorded during the late Atlantic (Fig. 11). This suggests that the mixed deciduous woodlands in this part of the Rhine river floodplain were dominated by oak. The dominance of oak in these forests indicates that in this area the groundwater level during summer was low (compare Ellenberg, 1996). In the northeastern part (north of Crumstadt), pine remained the dominant tree. Birch, willow and poplar (Populus) probably fringed the rivers and residual channels. In the residual channels of the Neckar, alder carrs with alder (Alnus glutinosa) and ferns developed, while in those of the Rhine, the hydroseral succession never reached the woodland stage (Fig. 12b).

During the Atlantic, human interference in the landscape became an important new factor influencing the palaeoecological conditions, vegetation development and associated fluvial processes. With the introduction of agriculture and clearance of forests by Neolithic people, the impact on the natural landscape increased. In the pollen diagrams representing this period, the increase of oak and decrease of hazel, elm and lime points to openings in the forests, probably caused by early farmers (Schweizer, 2005). The presence of cereal pollen as a primary indicator for agriculture supports this interpretation (Figs 3 and 5). Also the higher values of ash (Fraxinus) in the Grosse Lache (Fig. 11) and Wasserbiblos diagrams (Fig. 4) suggest human interference that could be ascribed to the Early Neolithic (Kalis et al., 2003). The first farmers of the Early Neolithic Linear Bandkeramik culture reached the loess areas in central Germany around $7450 \mathrm{cal} \mathrm{BP}$, i.e. approximately two centuries earlier than on the rest of the northern European mainland (Kalis et al., 2003). The Grosse Lache diagram shows at the end of the Atlantic a pronounced decrease in the Ulmus values, which was dated at $6200 \mathrm{cal}$ BP (Fig. 2). This elm-decline in the northern Upper Rhine area is approximately synchronous with that of the adjacent Wetterau (Stobbe, 1996).

The introduction of agriculture and clearing of forests by Neolithic people during the Atlantic in south and central Germany (e.g. Schneider, 2000; Kalis et al., 2003) probably resulted in a reduction in the evapotranspiration and an increase in the run-off. During the early Atlantic the river Rhine initially maintained the same meandering pattern as during the Boreal and overbank deposition of sandy silt and loams continued (Dambeck \& Thiemeyer, 2002). However, later during the Atlantic there is a rapid change in the fluvial system as the river Rhine changes to a new meander belt, the older meander generation (Fig. 1). Related to this shift in river pattern sedimentation patterns changed and deposition of predominantly silty clays and clays, i.e., black clays, started (Dambeck \& Thiemeyer, 2002) (Fig. 12b).

\section{Subboreal}

During the Subboreal human impact increased and woodlands thinned in the northern Upper Rhine Graben. The remaining woodlands consisted mainly of oak (Quercus), lime (Tilia), hazel (Corylus) and beech (Fagus) (Fig. 12b). Pine persisted in the sand dune areas. On the river floodplains mixed deciduous woodlands were partly replaced by meadows and fields (Fig. $12 b)$. In some areas the clearing of forests by late Neolithic people induced aeolian activity and translocation of dune sands. This aeolian phase was dated at ca. 6000 cal BP (Dambeck, 2005).

The river Rhine continued to develop the older meander belt, which was characterised by larger meanders in the northern part of the research area and more straightened river channels in the southern part (Dambeck \& Thiemeyer, 2002). In the floodplain deposition of black clays continued (Fig. 12b).

\section{Subatlantic}

The Subboreal/Subatlantic (i.e. Bronze Age/Iron Age) transition was dated at $2750 \mathrm{BP}$ (2800 cal BP) and was characterised by an abrupt change from a relatively warm and continental climate to cooler and wetter conditions (Van Geel et al., 1996, 1998a, b). This abrupt climate change was synchronous over Europe and other continents and was forced by a decline in solar activity (Kilian et al., 1995; Van Geel et al., 1996, 1998a, b). 
During the early Subatlantic human activity further increased (Hermann \& Jockenhövel, 1990). The pollen diagrams representing this period (Figs 5 and 11) show a strong increase in the NAP and Cerealia pollen values, while typical anthropogenic indicators such as rye (Secale cereale), narrowleaf plantain (Plantago lanceolata) and cornflower (Centaurea cyanus) are present. In the northern Upper Rhine Graben the natural woodlands were largely replaced by meadows and fields (Fig. 12b). The remaining woodlands consisted mainly of beech. For a detailed palynological study in the Neckar area see Singer (2004).

The wetter climate in combination with an enhanced deforestation and intense human activity (Iron Age agriculture) caused instability of the soils and an increase in surface erosion and run-off. Large amounts of waterlogged sediment became available and in the valleys colluvial deposits developed on a big scale (Fig. 12b). In the Rhine river valley, at sites where the original soil was eroded, the expansion of pine woodlands was favoured. Near the residual channels, wet meadows replaced the existing alder carr vegetation. These palaeoenvironmental changes caused a raise of the groundwater level and in the residual channels aquatic vegetation with pondweed and white water lily reappeared. A reed swamp fringed the banks.

The river Rhine started to develop a new meander belt during the early Subatlantic, i.e. the younger meander generation (Fig. 1). This meander belt is in some parts of the river valley characterised by very large meanders (resembling a cows head or 'Kühkopf', Fig. 1). In other reaches a straightening of the river channels and narrowing of the floodplain occurred (Dambeck \& Thiemeyer, 2002). The differential development in various parts of the northern Upper Rhine river valley suggests an independent development of these fluvial systems (sensu Buch, 1988). Related to the shift to a new meander belt, deposition of overbank sediments changed; deposition of mainly clays that characterised the late Atlantic and Subboreal ceased and shifted to deposition of predominantly silty sands and sandy silts. This indicates a change in the fluvial morphodynamics and sedimentological conditions. The change in river pattern was probably induced both by the abrupt climate change to a cooler, wetter climate at the Subboreal/Subatlantic transition (Van Geel et al., 1996; 1998a, b) as well as by the intensification of human impact during this period (Hermann \& Jockenhövel, 1990; Fetzer et al., 1995). As a consequence of the wetter climate in Europe and deforestations in our research area and hinterland (compare Burga, 1988; Lotter, 1999; Schneider, 2000; Mäckel et al., 2003), run-off was enhanced and large amounts of waterlogged sediment flowed into the river Rhine causing the change in the meandering pattern. The effects of human impact were probably intensified by superposition of climatic causes or vice versa.

\section{Conclusions}

In this paper the vegetation history of the northern Upper Rhine Graben (southwestern Germany) during the past 13,000 years was reconstructed. During this period, the composition of the woodland vegetation was mainly controlled by climate, but especially during the Holocene, differences in substrate, variations in annual precipitation and human impact also influenced the composition of the natural woodland vegetation.

Analogous to adjacent lowland areas, the Younger Dryas climatic deterioration did not result in a complete deforestation of the area and open pine woodlands with locally birch stands and shrubs persisted. Open herbaceous communities, however, had a greater abundance in the sand dune area in the northeastern part of the research area, while pine was more abundant in the southeastern part. A bipartition of the Younger Dryas period into a humid first phase followed by a dry second phase is suggested by our records. Pollen analysis on different residual channel fills of the Bergstrassen-Neckar revealed that complete abandonment of the river occurred at the Younger Dryas/Preboreal transition. The river Rhine probably continued meandering during the Younger Dryas.

During the early Preboreal, palaeoenvironmental conditions stabilised; the research area became densely forested with pine and soils developed. Closed pine woodlands especially inhabited the drier northeastern sand dune area. Birch stands were more abundant in the south eastern part, which was probably related to the higher precipitation received by that area. The start of the late Preboreal is characterised by a temporal increase in the amount of birch stands on the river floodplains, which can be observed over larger areas in south and central Germany. This oscillation is probably the reflection of a sudden shift to a more humid climate and is contemporaneous with the terrestrial Preboreal Oscillation as described in many North Atlantic terrestrial records. Hazel migrates into the Rhine and Neckar river valleys at the end of the Preboreal.

The major expansion of hazel, however, occurs during the early Boreal. This was followed by oak, elm and later also by lime. As soon as hazel expands, differences in the woodland composition within the area become larger, i.e. in the southern part of the research area, hazel becomes dominant, while pine dominates the northern area far into the Subboreal. This can be explained by the presence of large sand dune fields in the northeastern part and by the lower annual precipitation that hampered the expansion of hazel. During the Boreal and early Atlantic, woodlands became denser and large parts of the river valleys were forested with oak. The increased density of the vegetation cover in the research area and Rhine hinterland and higher evapotranspiration during the Boreal probably caused a gradual shift in the Rhine meandering pattern. The new meanders were characterised by a decrease in radius and channel width and more single-thread channels developed. 
During the Atlantic, mixed deciduous woodlands with elm, lime, hazel and oak were present in the floodplains of the Rhine. The riverine forests of the Rhine were dominated by oak, often together with hazel and elm. Alder carrs developed in the residual channels of the Bergstrassen Neckar. On the northeastern sand dune area pine remained dominant. From the Atlantic onwards, the impact of man on the natural landscape intensified with the introduction of agriculture and animal husbandry. During the late Atlantic there is a rapid change in the fluvial system as the river Rhine changes to a new meander belt, i.e. older meander generation. Related to this shift in river pattern, sedimentation patterns change and deposition of the so-called black clays started.

During the Subboreal and Subatlantic, the mixed deciduous woodlands in the river floodplains were almost completely replaced by meadows and arable fields. The increased deforestation and human agriculture in connection with the abrupt shift to a wetter and cooler climate at the Subboreal/ Subatlantic transition probably caused instability of the soils and an increase in the surface erosion. High amounts of sediment became available and during the Subatlantic largescale colluvium deposition took place in the valleys. Consequently a shift in the Rhine river pattern occurred and the Rhine started to develop a new meander belt during the early Subatlantic, i.e. younger meander generation. The shift in river pattern was induced by the abrupt change to a cooler and wetter climate in Europe as well by the intensification of human activity (Iron Age agriculture).

\section{Acknowledgements}

The two projects 'Flussgeschichte des nördlichen Oberrheines. Klimatische und anthropogene Ursachen und Auswirkungen vom Spätglazial bis zur frühen Neuzeit' (DFG projects: TH552/2-1, TH-552/3-2) and 'Paläoökologische Untersuchungen zur Vegetations- und Landschaftsgeschichte der Flussaue des nördlichen Oberrheins während des Spätglazials und frühen Holozäns' (DFG project: KA 752-5) were part of the priority program 'Changes of the geo-biosphere during the last 15,000 years, continental sediments as evidence for changing environmental conditions' funded by the Deutsche Forschungsgemeinschaft (DFG), Bonn. We are grateful to K.-J. Sabel and W. Rosenberger (HLUG) for valuable discussions. Furthermore, the Hessisches Landesamt für Bodenforschung (now Hessisches Landesamt für Umwelt und Geologie, HLUG, Wiesbaden) is acknowledged for technical and logistical support. L.M. Kerpvan der Brink, F.I. Braber and K. Sojka are thanked for pollen analysis, K. van der Borg (University Utrecht) is thanked for AMS ${ }^{14} \mathrm{C}$ dating and R. Urz (University Frankfurt) for selection of AMS ${ }^{14} \mathrm{C}$ samples. Many thanks also to Patrick Kiden and Wim Hoek for useful comments on an earlier draft of this paper. This is a Netherlands Research School of Sedimentary Geology publication No. 20050304.

\section{References}

Andres, W., Bos, J.A.A., Houben, P., Kalis, A.J., Nolte, S., Rittweger, H. \& Wunderlich, J., 2001. Environmental change and fluvial activity during the Younger Dryas in Central Germany. Quaternary International 79: 89-100.

Bartz, J., 1982. Quartär und Jungtertiär II im Oberrheingraben im Grossraum Karlsruhe. Geologisches Jahrbuch A63: 1-237.

Becker, E., 1967. Zur stratigraphischen Gliederung der jungpleistozänen Sedimente im nördlichen Oberrheintalgraben. Eiszeitalter und Gegenwart 18: 5-50.

Behre, K.E., 1966. Untersuchungen zur spätglazialen und frühpostglazialen Vegetationsgeschichte 0stfrieslands. Eiszeitalter und Gegenwart 17: 69-84

Behre, K.E., 1978. Die Klimaschwankungen im europaischen Präboreal. Petermanns Geographische Mitteilungen 2: 97-102.

Birks, H.J.B., 1986. Late-Quaternary biotic changes in terrestrial and lacustrine environments, with particular reference to north-west Europe. In: Berglund, B.E. (ed.): Handbook of Holocene Palaeoecology and Palaeohydrology. Wiley (Chichester): 3-65.

Björck, S., Kromer, B., Johnsen, S., Bennike, O., Hammarlund, D., Lehmdahl, G., Possnert, G., Rasmussen, T.L., Wohlfarth, B., Hammer, C.U. \& Spurk,

M., 1996. Synchronized Terrestrial-Atmospheric Deglacial Records Around the North Atlantic. Science 274: 1155-1160.

Björck, S., Rundgren, M., Ingólfsson, Ó. \& Funder, S., 1997. The Preboreal oscillation around the Nordic Seas: terrestrial and lacustrine responses. Journal of Quaternary Science 12: 455-465.

Blackmore, S., Steinmann, J.A.J., Hoen, P.P. \& Punt, W., 2003. The Northwest European Pollen Flora 65. Betulaceae and Corylaceae. Review of Palaeobotany and Palynology 123: 71-98.

Bohncke, S.J.P. \& Vandenberghe, J., 1991. Palaeohydrological Development in the Southern Netherlands during the Last 15000 years. In: Starkel, L., Gregory, K.J. \& Thornes, J.B. (eds): Temperate Palaeohydrology. Wiley \& Sons (Chichester): 253-281.

Bohncke S.J.P., Vandenberghe J. \& Huijzer, A.S., 1993. Periglacial environments during the Weichselian Late Glacial in the Maas valley, the Netherlands. Geologie en Mijnbouw 72: 193-210.

Bos, J.A.A., 1998. Aspects of the Lateglacial-Early Holocene Vegetation Development in Western Europe. Palynological and palaeobotanical investigations in Brabant (the Netherlands) and Hessen (Germany). PhD Thesis, University Utrecht. LPP Contribution Series 10: 240 pp.

Bos, J.A.A., 2001. Lateglacial and Early Holocene vegetation history of the northern Wetterau and the Amöneburger Basin (Hessen), central-west Germany. Review of Palaeobotany and Palynology 115: 177-212.

Bos, J.A.A. \& Urz, R., 2003. Late Glacial and early Holocene environment in the middle Lahn river valley (Hessen, central-west Germany) and the local impact of early Mesolithic people - pollen and macrofossil evidence. Vegetation History and Archaeobotany 12: 19-36.

Bos, J.A.A., Van Geel, B., Van der Plicht, J. \& Bohncke, S.J.P., 2007. Preboreal climate oscillations in Europe: wiggle-match dating and synthesis of Dutch high-resolution multi-proxy records. Quaternary Science Reviews 26: 1927 1950.

Buch, M.W., 1988. Spätpleistozäne und holozäne fluviale Geomorphodynamik im Donautal zwischen Regensburg und Straubing. Regensburger Geographische Schriften 21: 197 pp 
Burga, C.A., 1988. Swiss vegetation history during the last 18000 years. New Phytologist 110: 581-602.

Cappers, R.T.J., Bottema, S., Woldring, H., Van der Plicht, J. \& Streurman, H.J., 2002. Modelling the emergence of farming: implications of the vegetation development in the Near East during the Pleistocene-Holocene transition. Studies in Early Near eastern Produciton, Subsistence, and Environment 6: 3-14.

Dambeck, $R$., 2005. Beiträge zur spät- und postglazialen Fluss- und Landschaftsgeschichte im nördlichen Oberrheingraben, PhD Thesis, University Frankfurt/ Main: 246 pp. Online publication: http://publikationen.ub.uni-frankfurt.de/ volltexte/2005/908/

Dambeck, R. \& Bos, J.A.A., 2002. Lateglacial and Early Holocene landscape evolution of the northern Upper Rhine River valley, southwestern Germany. Zeitschrift für Geomorphologie N.F., Suppl. Bd. 128: 101-127.

Dambeck, R. \& Sabel, K.-J., 2001. Spät- und postglazialer Wandel der Flusslandschaft am nördlichen Oberrhein und Altneckar im Hessischen Ried. Jahresberichte und Mitteilungen des oberrheinischen geologischen Vereins, Neue Folge 83: 131-143.

Dambeck, R. \& Thiemeyer, H., 2002. Fluvial History of the northern Upper Rhine river (south-western Germany) during the Lateglacial and Holocene times. Quaternary International 93-94: 53-63.

Deneke, M., 1992. Grundwasserabsenkungen im Hessischen Ried oder die Technisierung der Äusseren Natur. In: Böhm, H. R. \& Deneke, M. (eds): Wasser: eine Einführung in die Umweltwissenschaften. Wissenschaftliche Buchgesellschaft (Darmstadt): 197-210.

Der Regierungspräsident in Darmstadt (eds), 1985. Wasserwirtschaftlichökologische Gesamtplanung Ried. Dokumentation (Darmstadt): 296 pp.

Deutscher Wetterdienst, 1981. Das Klima von Hessen (Offenbach): 115 pp.

Dommermuth, H. \& Trampf, W., 1990. Die Verdunstung in der Bundesrepublik Deutschland, Zeitraum 1951 - 1980, Teil 1. Deutscher Wetterdienst (Offenbach).

Ellenberg, H., 1996. Vegetation Mitteleuropas mit den Alpen in ökologischer, dynamischer und historischer Sicht. 5th ed. UTB für Wissenschaft: Grosse Reihe: $1095 \mathrm{pp}$

Faegri, K. \& Iversen, J., 1989. Textbook of Pollen Analysis. 4th ed. (revised by K. Faegri, P.E. Kaland \& Krzywinski, K.). Wiley \& Sons (Chichester): 328 pp.

Fetzer, K.D., Larres, K., Sabel, K.-J., Spies, E.-D. \& Weidenfeller, M., 1995 Hessen, Rheinland-Pfalz, Saarland. In: Benda, L. (ed.): Das Quartär Deutschlands. Borntraeger (Stuttgart): 220-254.

Firbas, F., 1949. Spät- und nacheiszeitliche Waldgeschichte Mitteleuropas nördlich der Alpen. Vol. 1. Fischer (Jena): 480 pp.

Firbas, F., 1952. Das Oberrheinische Tiefland. In: Spät- und nacheiszeitliche Waldgeschichte Mitteleuropas nördlich der Alpen. Vol. 2. Fischer (Jena) 43-49.

Grosse-Brauckmann, G., Malchow, G. \& Streitz, B., 1990. Makrofossil- und pollenanalytische Befunde vom Altneckarbett bei Riedstadt-Goddelau, Kreis Gross-Gerau. Materialien Vor- und Frühgeschichte Hessen 5: 111-132.

Grimm, E.C., 1991 - 2004. TILIA, TILA.GRAPH, and TGView. Illinois State Museum, Research and Collections Center, Springfield, USA (http://demeter.museum. state.il.us/pub/grimm/)

Hendl, M., 1994. Klima. In: Liedtke, H. \& Marcinek, J. (eds): Physische Geographie Deutschlands. Perthes (Gotha): 23-119.

Hessisches Landesamt für Bodenforschung (eds), 1990. Bodenkarte der nördlichen Oberrheinebene 1:50000; Wiesbaden.
Hermann, F.-R. \& Jockenhövel, A. (eds), 1990. Die Vorgeschichte Hessens. Theiss Verlag (Stuttgart): $534 \mathrm{pp}$.

Hölzer, A. \& Hölzer, A., 1994. Studies on the Vegetation history of the Lautermoor in the Upper Rhine valley (SW-Germany) by means of pollen, macrofossils, and geochemistry (Festschrift Gerhard Lang). Dissertationes Botanicae 234: 309-336.

Isarin, R.F.B., Renssen, H. \& Vandenberghe, J., 1998. The impact of the North Atlantic Ocean on the Younger Dryas climate in northwestern and central Europe. Journal of Quaternary Science 13: 447-453.

Kalis, A.J., Merkt, J. \& Wunderlich, J., 2003. Environmental changes during the Holocene climatic optimum in central Europe - human impact and natural causes. Quaternary Science Reviews 22: 33-79.

Kalis, A.J. \& Schweizer, A., 2002. Paläoökologische Untersuchungen zur Vegetations- und Landschaftsgeschichte der Flussaue des nördlichen Oberrheins während des Spätglazials und frühen Holozäns. Abschlussbericht DFG-Projekt Ka 752/5, Schwerpunktprogramm 'Wandel der Geo-Biosphäre während der letzten 15000 Jahre': 12 pp.

Kärcher, Th., 1987. Beiträge zur Lithologie und Hydrogeologie der Lockergesteinsablagerungen (Pliozän, Quartär) im Raum Frankenthal, LudwigshafenMannheim, Speyer. Jahresberichte und Mitteilungen des oberrheinischen geologischen Vereins, Neue Folge 69: 279-320.

Klausing, 0., 1988. Die Naturräume Hessens mit einer Karte der naturräumlichen Gliederung 1:200 000. Schriftenreihe Hessisches Landesamt für Umwelt und Geologie 67: $43 \mathrm{pp}$.

Kilian, M.R., Van der Plicht, J. \& Van Geel, B., 1995. Dating of raised bogs: new aspects of AMS ${ }^{14} \mathrm{C}$ AMS wiggle matching, a reservoir effect and climate change. Quaternary Science Reviews 14: 959-966.

Kupfahl, H.-G., Meisl, S.\& Kümmerle, E., mit Beiträgen von Bargon, E., Böke, E., Diederich, G., Kutscher, F., Matthess, G., Prinz, H., Schwarz, E., Thielicke, G. \& Wendler, R., 1972. Erläuterungen zur Geologischen Karte von Hessen $1: 25,000$, Blatt 6217 Zwingenberg an der Bergstrasse: 276 pp.

Küttel, M., Löscher, M. \& Hölzer, A., 1986. Ergebnisse paläobotanischer Untersuchungen zur Stratigraphie und Ökologie des Würms im Oberrheingraben zwischen Karlsruhe uns Mannheim. Eiszeitalter und Gegenwart 36: 75-88.

Leroy, S.A.G., Zolitschka, B., Negendank, J.F.W. \& Seret, G., 2000. Palynological analyses in the laminated sediment of Lake Holzmaar (Eifel, Germany): duration of Lateglacial and Preboreal biozones. Boreas 29: 52-71.

Litt, T. (ed.), 2003. Environmental response to climate and human impact in central Europe during the last 15,000 years - a German contribution to PAGES-PEP III. Quaternary Science Reviews 22: 124.

Litt, T., Schmincke, H.-U. \& Kromer, B., 2003. Environmental response to climatic and volcanic events during the Weichselian Lateglacial. Quaternary Science Reviews 22: 7-32

Lotter, A.F., 1999. Late-glacial and Holocene vegetation history and dynamics as shown by pollen and plant macrofossil analyses in annually laminated sediments from Soppensee, central Switzerland. Vegetation History and Archaeobotany 8: 165-184.

Lotter, A.F., Eicher, U., Birks, H.J.B. \& Siegenthaler, U., 1992. Late-glacial climatic oscillations as recorded in Swiss lake sediments. Journal of Quaternary Science 7: 187-204. 
Löscher, M., 1988. Stratigraphische Interpretation der jungpleistozänen Sedimente in der Oberrheinebene zwischen Bruchsal und Worms. In: Von Koenigswald, W. (ed.): Zur Paläoklimatologie des letzten Interglazials im Nordteil der Oberrheinebene. Paläoklimaforschung 4: 79-104.

Löscher, M. \& Haag, Th., 1989. Zum Alter der Dünen im nördlichen Oberrheingraben bei Heidelberg und zur Genese ihrer Bänderparabraunerden. Eiszeitalter und Gegenwart 39: 98-108.

Lowe, J.J., Ammann, B., Birks, H.H., Björck, S., Coope, G.R., Cwynar, L., De Beaulieu, J.-L., Mott, R.J., Peteet, D.M. \& Walker, M.J.C., 1994. Climatic changes in areas adjacent to the North Atlantic during the last glacialinterglacial transition (14 - $9 \mathrm{ka} \mathrm{BP}$ ): a contribution to IGCP-253. Journal of Quaternary Science 9: 185-198.

Mäckel, R., Schneider, S. \& Seidel, J., 2003. Antropogenic impact on the landscape of southern Badenia (Germany) during the Holocene documented by colluvial and alluvial sediments. Archaeometry 45: 487-501.

Mangold, A., 1892. Die alten Neckarbetten in der Rheinebene. Abhandlungen der grossherzoglichen hessischen geologischen Landesanstalt Darmstadt 2: 57-114.

Marcenko, E., Srdoc, D., Golubic, S., Pezdic, J. \& Head, M.J., 1989. Carbon uptake in aquatic plants deduced from their natural ${ }^{13} \mathrm{C}$ and ${ }^{14} \mathrm{C}$ content. Radiocarbon 31: 785-794

Moore, P.D., Webb, J.A. \& Collinson, M.E., 1991. Pollen analysis. 2nd ed. Blackwell (0xford): $216 \mathrm{pp}$.

Nolte, S., 2000. Auensedimente der Wetter als Indikatoren für die spätglaziale und holozäne fluviale Morphodynamik in der nördlichen Wetterau, Hessen. Shaker Verlag (Aachen): $206 \mathrm{pp}$

Oberdorfer, E., 1934. Zur Geschichte der Sümpfe und Wälder zwischen Mannheim und Karlsruhe. Jahresbericht des Verein für Naturkunde Mannheim 100/101 99-124.

Oberdorfer, E., 1937. Zur spät- und nacheiszeitlichen Vegetationsgeschichte des Oberelsasses und der Vogesen. Zeitschrift für Botanik 30: 513-572.

Pflug, R., 1985. Bau und Entwicklung des Oberrheingrabens. Erträge der Forschung 184. Wissenschaftliche Buchgesellschaft (Darmstadt): 145 pp.

Punt, W. (ed.), 1976. The Northwest European Pollen Flora I. Elsevier Science Publishers (Amsterdam): $145 \mathrm{pp}$

Punt, W. \& Clarke G.C.S. (eds), 1980. The Northwest European Pollen Flora II Elsevier Science Publishers (Amsterdam): 265 pp.

Punt, W. \& Clarke, G.C.S. (eds), 1981. The Northwest European Pollen Flora III Elsevier Science Publishers (Amsterdam): 138 pp.

Punt, W. \& Clarke, G.C.S. (eds), 1984. The Northwest European Pollen Flora IV Elsevier Science Publishers (Amsterdam): 369 pp.

Punt, W., Blackmore, S. \& Clarke, G.C.S. (eds), 1988. The Northwest European Pollen Flora V. Elsevier Science Publishers (Amsterdam): 154 pp.

Punt, W. \& Blackmore, S. (eds), 1991. The Northwest European Pollen Flora VI Elsevier Science Publishers (Amsterdam): 275 pp.

Punt, W., Blackmore, S. \& Hoen, P.P. (eds), 1995. The Northwest European Pollen Flora VII. Elsevier Science Publishers (Amsterdam): 275 pp.

Punt, W., Blackmore, S., Hoen, P.P. \& Stafford, P.J. (eds), 2003. The Northwest European Pollen Flora VIII. Elsevier Science Publishers (Amsterdam): 183 pp.

Rasmussen, S.O., Vinther, B.M., Clausen, H.B. \& Andersen, K.K., 2007. Early Holocene climate oscillations recorded in three Greenland ice cores. Quaternary Science Reviews 26: 1907-1914.
Reimer, P.J., Baillie, M.G.L., Bard, E., Bayliss, A., Beck, J. W., Bertrand, C.J.H., Blackwell, P.G., Buck, C.E., Burr, G.S., Cutler, K.B., Damon, P.E. Edwards, R.L., Fairbanks, R.G., Friedrich, M., Guilderson, T.P., Hogg, A.G., Hughen, K.A., Kromer, B., McCormac, G., Manning, S., Bronk Ramsey, C., Reimer, R.W., Remmele, S., Southon, J.R., Stuiver, M., Talamo, S., Taylor, F.W., Van der Plicht, J. \& Weyhenmeyer, C.E., 2004. IntCal04 Terrestrial Radiocarbon Age Calibration, 0 - 26 cal kyr BP. Radiocarbon 46: 1029-1058.

Rosenberger, W., Weidner, E., Friedrich, K. \& Hottenrott, M., 1996. Geologische Karte von Hessen 1:25000, Blatt 6216 Gernsheim. Digitale Ausgabe; Wiesbaden.

Rothschild, S., 1936. Zur Geschichte der Moore und Wälder im Nordteil de Oberrheinischen Tiefebene. Botanisches Centralblatt, Beihefte 54: 140-184.

Schäfer, M., 1996. Pollenanalysen an Mooren des Hohen Vogelsberges (Hessen). Beiträge zur Vegetationsgeschichte und anthropogenen Nutzung eines Mittelgebirges. Dissertationes Botanicae 265: 280 pp.

Scharpff, H.-J, Anderle, H.-J., Böke, E., Brelie von der, G., Diederich, G., Karschny, A., Prinz, H., Reichmann, H., Schwarz, E., Ulrich, H.-J. \& Wendler, R., 1977. Erläuterungen zur Geologischen Karte von Hessen $1: 25,000$, Blatt 6316 Worms: 282 pp.

Scheer, H.-D., 1978. Gliederung und Aufbau der Niederterrassen von Rhein und Main im nördlichen Oberrheintalgraben. Geologisches Jahrbuch Hessen 106: 273-289.

Schirmer, W., 1983. Die Talentwicklung an Main und Regnitz seit dem Hochwürm. Geologisches Jahrbuch A71: 11-43.

Schneider, $R$., 2000. Landschafts- und Umweltgeschichte im Einzugsgebiet der Elz. PhD Thesis, Freiburg University: 178 pp.

Schweiss, D., 1988. Jungpleistozäne Sedimentation in der nördlichen Oberrheinebene. In: Von Koenigswald, W. (ed.): Zur Paläoklimatologie des letzten Interglazials im Nordteil der Oberrheinebene. Paläoklimaforschung 4: 19-78.

Schweizer, A., 2001. Archäopalyonologische Untersuchungen zur Neolithisierung der nördlichen Wetterau/Hessen - mit einer methodischen Beitrag zur Pollenanalyse in Lössgebieten. Dissertationes Botanicae 350: 158 pp.

Schweizer, A., 2005. Die Neolithisierung der Wetterau (Hessen) aus archäopalynologischer Sicht. In: Lüning, J. Frirdich, C. \& Zimmermann, A. (eds): Die Bandkeramik im 21. Jahrhundert. Internationale Archäologie: Arbeitsgemeinschaft, Symposium, Tagung, Kongress 7. Leidorf Verlag (Rahden/Westf.): 289-297.

Semmel, A., 1994. Das Süddeutsche Stufenland mit seinen Grundgebirgsrändern. In: Liedtke, H. \& Marcinek, J. (eds): Physische Geographie Deutschlands. Julius Perthes (Gotha): 389-437.

Singer, C., 2004. Die Vegetation des nördlichen Hessischen Rieds während der Eisenzeit, der Römischen Kaiserzeit und dem Frühmittelalter - Pollenanalytische Untersuchungen zur Vegetationsgeschichtlichen Rekonstruktion eines Natur- und Siedlungsraumes unter romischem Einfluss. PhD Thesis, University Frankfurt/Main: 174 pp.

Sojka, K., 2002. Rekonstruktion der holozänen Vegetations- und Landschaftsentwicklung der nördlichen Oberrheinebene mittels palynologischer Untersuchungen von Neckaraltlauf-sedimenten. Masters Thesis, University Frankfurt/Main (internal report): $98 \mathrm{pp}$

Stark, P., 1926. Ein altes Moorprofil im Oberrheintal bei Mannheim. Berichte der Deutschen Botanischen Gesellschaft 44: 373-376 
Stobbe, A., 1996. Die holozäne Vegetationsgeschichte der nördlichen Wetterau paläoökologische Untersuchungen unter besonderer Berücksichtigung anthropogener Einflüsse. Dissertationes Botanicae 260: 216 pp.

Stuiver, M., \& Reimer, P.J., 1993. CALIB Radiocarbon calibration program. Radiocarbon 35: 215-230.

Törnqvist, T.E., De Jong, A.F.M., Oosterbaan, W.A. \& Van der Borg, K., 1992. Accurate dating of organic deposits by AMS ${ }^{14} \mathrm{C}$ measurement of macrofossils. Radiocarbon 34: 566-577.

Urz, R., 1995. Jung-Quartär im Auenbereich der mittleren Lahn. Stratigraphische und paläontologische Untersuchungen zur Rekonstruktion vergangener Flusslandschaften. PhD Thesis, University Marburg: 198 pp.

Vandenberghe, J., 1995. The role of rivers in palaeoclimatic reconstruction. In: Frenzel, B. (ed.): European river activity and climatic change during the Lateglacial and early Holocene. Paläoklimaforschung 14: 11-19.

Vandenberghe, J. \& Bohncke, S.J.P., 1985. The Weichselian Late Glacial in a small lowland valley (Mark river, Belgium and the Netherlands). Bulletin de l'Association française pour l'Étude du Quaternaire 2-3: 167-175.

Van Geel, B., Bohncke, S.J.P. \& Dee, H., 1981. A palaeoecological study of an Upper Late Glacial and Holocene sequence from 'de Borchert', the Netherlands. Review of Palaeobotany and Palynology 31: 367-448.

Van Geel, B., Buurman, J. \& Waterbolk, H.T., 1996. Archaeological and palaeoecological indications of an abrupt climate change in the Netherlands, and evidence for climatological teleconnections around $2650 \mathrm{BP}$. Journal of Quaternary Science 11: 451-460.

Van Geel, B., Van der Plicht, J., Kilian, M.R., Klaver, E.R., Kouwenberg, J.H.M., Renssen, H., Reynaud-Farrera, I. \& Waterbolk, H.T., 1998a. The sharp rise of $\delta^{14} \mathrm{C}$ ca. 800 cal BC: possible causes, related climatic connections and the impact on human environments. Radiocarbon 40: 535-550.

Van Geel, B., Raspopov, O.M., Van der Plicht, J. \& Renssen, H., 1998b. Solar forcing of abrupt climate change around 850 calendar years BC. In: Peiser, B.J., Palmer, T. \& Bailey, M.E. (eds): Natural catastrophes during the Bronze Age civilisations. BAR International Series 728: 162-168.

Van der Plicht, J., Van Geel, B., Bohncke, S.J.P., Bos, J.A.A., Blaauw, M., Speranza, A.O.M., Muscheler, R. \& Björck, S., 2004. The Preboreal climate reversal and a subsequent solar-forced climate shift. Journal of Quaternary Science 19: 263-269.

Walter, R., 1995. Geologie von Mitteleuropa, Schweizerbart (Stuttgart): 566 pp. Zakosek, H., 1962. Zur Genese und Gliederung der Steppenböden im nördlichen Oberrheintal. Abhandlungen des Hessichen Landesamtes für Bodenforschung 37: $1-46$.

Zakosek, H., 1991. Zur Genese und Gliederung des Rheintal-Tschernosems im nördlichen Oberrheingraben. Mainzer geowissenschaftliche Mitteilungen 20: 159-176. 